\title{
Evaluasi Program - Program Strategis Pemerintah Kota Bandung Di Bidang Ekonomi dalam Upaya Penguatan dan Peningkatan Kemampuan Daya Beli Masyarakat : Suatu Tinjauan Analisis Kebijakan Publik
}

\author{
Bayu Kharisma
}

Universitas Padjadjaran

\begin{abstract}
This study aims to evaluate and prioritize the various forms of strategic programs at the Bandung City Government in strengthening the economy and increasing purchasing power of the people in the city of Bandung based on public policy analysis. This study is comprehensive covering macro aspects, namely the potential and economic profile as well as the Human Development Index (HDI) and micro aspects, namely the external and internal environmental analysis relating to economic policy on purchasing power. Furthermore, evaluation and economic policy priorities in an effort to increase the purchasing power of the city of Bandung.
\end{abstract}

There are few steps or effort in evaluating various forms of local government strategic program Bandung in economics in order to increase the purchasing power of the city of Bandung, namely: 1) Observing the potential and the problems by SWOT analysis (strengths, weaknesses, opportunities, threats). 2) Evaluation and prioritization of programs of economic analysis AHP (analytical hierarchy process) and connect it to the macroeconomic indicators Bandung. In conducting the evaluation and priority, strategic programs are done also based on the study of literature and discussions with experts. The number of respondents in this study is 15 (fifteen) and sampling was done by purposive convenience sampling.

Based Matrix EFAS (External Strategic Factors Analysis Summary) shows that the Bandung City Government is in a strong position to exploit the opportunities that exist to minimize the threats that will arise with regard to the external factors that affect the purchasing power of the city of Bandung. The Government of Bandung can utilize the opportunities, which are significant factors, in order to increase the purchasing power of the people. These are plans such as: the Central Government Policies Regarding Rice for the Poor (RASKIN), Health Insurance for the Poor (insurance for the poor), and the School Operational Assistance (BOS), National Program Community Empowerment (PNPM), the People's Business Credit (KUR) with Interest Subsidy to Help Low Income Communities .

Furthermore, from the results of Matrix IFAS (Internal Strategic Factor Analysis Summary) shows that the Bandung City Government is in a relatively strong position to use and harness the forces that exist to minimize the shortcomings encountered in efforts to improve the people's purchasing power. Internal factors that significantly influence the increase in purchasing power of the city of Bandung are the strong commitment of the Government of Bandung to increase purchasing power. Meanwhile, the biggest disadvantage factor and should be watched and minimized by the Bandung City Government in improving the purchasing power of the city of Bandung is a "Weak Monitoring and Evaluation Capability Strengthening Program Buy".

The estimation results of AHP (analytical hierarchy process) to local agencies regarding the analysis of preference evaluation of Government programs of 


\section{Bayu Kharisma}

Bandung in economics in improving and strengthening the purchasing power suggests that external factors are the priority aspects. Meanwhile, based on analysis of the preferences of businesses, communities and government agencies to the actors who play an important role in strengthening the purchasing power of the city of Bandung show that the relevant local government agencies play an important role in influencing people's purchasing power state through a set of policies and programs it has taken.

Keyword: Government in strengthening the economy and increasing purchasing power of the people in the city of Bandung, public policy analysis. SWOT analysis, Matrix EFAS and IFAS, AHP (Analytical Hierarchy Process)

\section{LATAR BELAKANG}

Dalam perencanaan pembangunan dewasa ini, pembangunan manusia senantiasa berada di fokus pembahasan terdepan. Pembangunan manusia (human development) dirumuskan sebagai perluasan pilihan bagi penduduk (enlarging the choice of people), yang dapat dilihat sebagai proses upaya ke arah "perluasan pilihan" dan sekaligus sebagai taraf yang dicapai dari upaya tersebut (UNDP, 1990). Di antara berbagai pilihan tersebut, pilihan yang terpenting adalah untuk berumur panjang dan sehat, untuk berilmu pengetahuan dan untuk mempunyai akses terhadap sumber daya yang dibutuhkan agar dapat hidup secara layak. Pilihan lainnya yang tak kalah pentingnya adalah kebebasan politik, jaminan atas hak asasi manusia dan harga diri. Dengan demikian, pembangunan manusia tidak hanya memperhatikan peningkatan kemampuan manusia, seperti meningkatkan kesehatan dan pendidikan. Pembangunan manusia diarahkan untuk meningkatkan partisipasi masyarakat dalam proses dan kegiatan pembangunan. Keberhasilan pembangunan dewasa ini dapat dilihat dari pencapaian kualitas sumber daya manusia yang ada di daerah tersebut. Untuk mencapai tujuan tersebut, Pemerintah Daerah melakukan kebijakan untuk meningkatkan kualitas SDM di wilayahnya, baik dari aspek fisik, aspek intelektualitas (pendidikan) dan aspek kesejahteraan ekonomi (daya beli) sehingga partisipasi rakyat dalam pembangunan akan meningkat.

Menurut UNDP (1995), paradigma pembangunan manusia terdiri dari 4 (ermpat) komponen utama, yaitu : (1) Produktifitas, masyarakat harus dapat meningkatkan produktifitasnya dan berpartisipasi secara penuh dalam proses memperoleh penghasilan. Oleh karena itu, pertumbuhan ekonomi merupakan salah satu bagian dari jenis pembangunan manusia, (2) Ekuitas, masyarakat harus punya akses untuk memperoleh kesempatan yang adil. Semua hambatan terhadap peluang ekonomi dan politik harus dihapus agar masyarakat dapat berpartisipasi di dalam dan memperoleh manfaat dari kesempatan-kesempatan ini, (3) Kesinambungan, akses untuk memperoleh kesempatan harus dipastikan tidak hanya untuk generasi sekarang tapi juga generasi yang akan datang. Segala bentuk permodalan fisik, manusia, lingkungan hidup, harus dilengkapi, (4) Pemberdayaan, pembangunan harus dilakukan oleh masyarakat dan bukan hanya untuk mereka. Masyarakat harus berpartisipasi penuh dalam mengambil keputusan dan proses-proses yang mempengaruhi kehidupan mereka.

Model pembangunan manusia ditujukan untuk memperluas pilihan masyarakat yang dapat dikembangkan melalui upaya pemberdayaan masyarakat. Hal tersebut dapat dicapai antara lain melalui upaya yang menitikberatkan pada peningkatan kemampuan dasar manusia yaitu meningkatnya derajat kesehatan, pengetahuan dan keterampilan serta kesejahteraan ekonomi agar dapat digunakan untuk meningkatkan partisipasi masyarakat itu sendiri dalam kegiatan pembangunan. Agar upaya tersebut dapat dicapai, informasi mengenai kualitas pembangunan manusia sangat penting untuk 
diketahui, yaitu melalui Indeks Pembangunan Manusia (IPM). Indeks Pembangunan Manusia (IPM) merupakan indeks komposit yang paling banyak digunakan sebagai salah satu alat untuk mengukur taraf kualitas fisik penduduk dan kemajuan pembangunan ekonomi. Oleh karena itu, pencapaian angka IPM di suatu daerah seringkali menjadi acuan bagi berhasil atau tidaknya proses pembangunan.

Pencapaian angka IPM tinggi merupakan salah satu harapan dan tujuan utama bagi setiap daerah, termasuk bagi Kota Bandung yang memiliki komitmen kuat untuk mengakselerasi pencapaian pada kesejahteraan masyarakat. Akselerasi tersebut diperlukan karena menyadari pentingnya untuk mempersiapkan diri dalam mengantisipasi perubahan-perubahan sebagai dampak globalisasi yang terjadi di Indonesia. Besarnya perhatian Pemerintah Kota Bandung terhadap upaya pencapaian indeks pembangunan manusia (IPM) sangat beralasan karena untuk memperkuat perekonomian harus dibuktikan melalui kesejahteraan masyarakat daerahnya. Walaupun tidak mempengaruhi secara langsung, pencapaian angka IPM yang tinggi sangat penting bagi usaha meningkatkan kesejahteraan masyarakat. Hal ini tercermin dengan adanya perbaikan sumberdaya manusia, maka akan berdampak positif terhadap peningkatan kesempatan kerja, peningkatan produktivitas dan peningkatan pendapatan daerah sehingga pada gilirannya akan meningkatkan kesejahteraan masyarakat di daerah tersebut.

Komitmen kuat Pemerintah Daerah Kota Bandung dalam upaya untuk menciptakan angka IPM tinggi, sebenarnya secara implisit tertuang dari Visi Kota Bandung dalam jangka panjang tahun 2004-2008 yaitu "Terwujudnya Kota Bandung Sebagai Kota Jasa yang Bermartabat (Bersih, Makmur, Taat dan Bersahabat)". Makna yang tertuang dari visi tersebut adalah Kota Bandung sebagai Kota Jasa yang dapat memberikan kemakmuran terhadap masyarakatnya serta kebijakan ekonomi yang mengupayakan peningkatan kegiatan perekonomian kota yang berbasiskan potensi daerah yang dituangkan ke dalam 8 (delapan) program strategis, yaitu : 1) Program Pembinaan dan Pengembangan Usaha Industri, 2) Program Pembinaan dan Pengembangan Usaha Perdagangan, 3) Program Pembinaan dan Pengembangan Usaha Koperasi, 4) Program Pembinaan Usaha Kecil, 5) Program Peningkatan Investasi Kota, 6) Program Pembinaan Pemasaran Parawisata, 7) Program produk keparawisataan dan 8) Program Pengembangan Agribisnis. Selain itu, bukti komitmen kuat lainnya dari pemerintah daerah Kota Bandung terhadap penguatan daya beli masyarakat diwujudkan dengan adanya program bantuan walikota, khusus bidang kemakmuran (Bawaku Makmur) yang merupakan dana hibah yang diberikan oleh pemerintah untuk dapat digunakan untuk menunjang ekonomi yang produktif, dengan harapan akan meningkatkan pendapatan dan daya beli para penerima bantuan tersebut.

Berdasarkan data BPS Jawa Barat tahun 2003 sampai dengan 2007, menunjukkan bahwa Indeks Pembangunan Manusia (IPM) Daerah Kota Bandung masih jauh lebih baik jika dibandingkan dengan Propinsi Jawa Barat. Pada tahun 2003, IPM Kota Bandung mencapai 77,15 sedangkan Propinsi Jawa Barat hanya 68,87. Pada tahun 2007 IPM Kota Bandung mencapai 78,09 atau naik mengalami kenaikan dari tahun sebelumnya sebesar 0,58 poin, sedangkan untuk Propinsi Jawa Barat mengalami kenaikan yang cukup signifikan mencapai sebesar 0,75 poin $(70,8)$ dari tahun sebelumnya, namun masih tetap di bawah IPM Kota Bandung. Hal ini dapat dilihat pada Grafik 1. di bawah ini. 


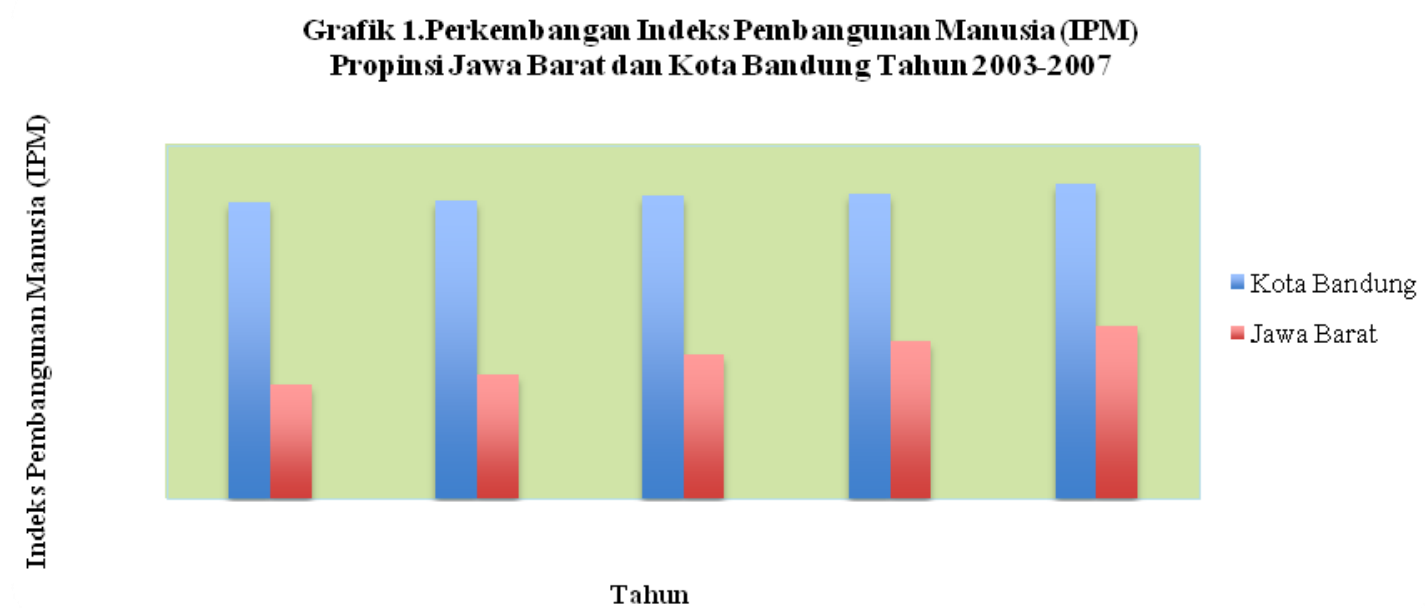

Sumber : BPS Provinsi Jawa Barat, 2007

Namun dibalik tingginya tingkat capaian keberhasilan pembangunan Kota Bandung (yang tercemin dari angka IPM) selama tahun 2003 sampai dengan 2007, ternyata tidak ditandai oleh peningkatan yang cukup signifikan pada salah satu komponen IPM, yaitu indeks daya beli (IDB) yang masih menunjukkan perkembangan cukup lambat. Apabila dilihat dari data yang diperoleh dari BPS Kota Bandung, secara umum Indeks Daya Beli (IDB) menunjukkan ada kenaikan setiap tahunnya. Namun apabila diperhatikan dari kehidupan masyarakat yang sebenarnya, justru mengalami kesulitan/keterpurukan serta masih banyaknya terdapat kepala keluarga yang tergolong miskin.

Tabel 1. Capaian Keberhasilan Pembangunan Kota Bandung Tahun 2004-2007

\begin{tabular}{|c|l|c|c|c|c|}
\hline No & \multicolumn{1}{|c|}{ Indikator } & $\mathbf{2 0 0 4}$ & $\mathbf{2 0 0 5}$ & $\mathbf{2 0 0 6}$ & $\mathbf{2 0 0 7}$ \\
\hline 1. & $\begin{array}{l}\text { Indeks Pembangunan } \\
\text { Manusia }\end{array}$ & 77,17 & 77,42 & 77,51 & 78,09 \\
\hline 2. & IPM = (IP+IK+IDB)/3 & 63,35 & 63,93 & 63,99 & 64,01 \\
\hline 3. & Penduduk Miskin & 75.47 & 84.50 & 82.87 & 81,32 \\
\hline
\end{tabular}

Sumber : BPS diolah Kantor Litbang Kota Bandung, 2007

Melambatnya perkembangan indeks daya beli masyarakat yang terjadi di Kota Bandung tidak terlepas dari semakin rendahnya kemampuan daya beli masyarakat yang antara lain disebabkan oleh dampak krisis ekonomi tahun 1997 yang sampai saat ini masih terasa, tekanan inflasi yang sangat berat karena adanya kenaikan harga BBM sejak tahun 2005 dan terakhir bulan April tahun 2008 yang mencapai $28,7 \%$. (Laporan Bank Indonesia, 2009). Selain itu, meningkatnya harga beberapa komoditas penting yang diimpor dan tingginya kenaikan harga beberapa komoditas bahan makanan yang harganya berfluktuasi (volatile food) serta meningkatnya permintaan masyarakat dan ekspektasi inflasi menjelang bulan Ramadhan dan hari raya Idul Fitri. Harga minyak goreng di pasar domestik juga mengalami kenaikan akibat terus naiknya harga minyak sawit mentah (CPO) dunia. Demikian pula harga minyak tanah mengalami kenaikan sebagai dampak kelangkaan bahan bakar tersebut terkait dengan pengurangan pasokan oleh Pertamina dalam rangka kebijakan konversi bahan bakar minyak tanah ke gas elpiji sebagai akibat naiknya minyak mentah dunia. Di samping bahan makanan, biaya pendidikan juga meningkat sehubungan awal tahun ajaran baru. Dengan adanya peristiwa tersebut, bahkan tidak mungkin akan menimbulkan rasa putus asa bagi orang-orang tertentu yang cenderung pesimistis. 
Apabila kondisi tersebut dibiarkan maka akan berdampak pada Indeks Pembangunan Manusia (IPM) itu sendiri serta jumlah masyarakat yang miskin di Kota Bandung akan semakin meningkat, dimana tidak bisa dipungkiri bahwa rendahnya daya beli merupakan salah satu sumber penyebab kemiskinan. Hal ini tidak bisa dibiarkan terus terjadi, pemerintah daerah dituntut untuk meningkatkan kembali kemampuan daya beli masyarakat dengan berbagai kebijakan, program dan kegiatan. Selain itu, perlu disadari bahwa Kota Bandung merupakan salah satu penopang utama dapat terwujudnya visi dan misi Jawa Barat menjadi propinsi termaju dan terdepan di Indonesia dengan pencapaian IPM 80 pada tahun 2010. Dengan pencapaian angka IPM yang relatif tinggi di Jawa Barat, maka Kota Bandung diharapkan dapat menjadi salah satu kota terdepan dalam pencapaian angka IPM lebih dari 80 pada tahun 2010. Memperhatikan latar belakang serta tema utama penyusunan studi ini, maka beberapa masalah yang akan dicermati adalah sebagai berikut :1) Mengidentifikasikan faktor-faktor internal dan eksternal yang berpengaruh terhadap kemampuan daya beli masyarakat Kota Bandung. 2) Melakukan evaluasi dan prioritas terhadap kebijakan ekonomi Pemerintah Kota Bandung yang dituangkan dalam berbagai bentuk program dalam upaya penguatan dan peningkatan kemampuan daya beli masyarakat Kota Bandung.

\section{DASAR TEORI}

\subsection{Teori Kebijakan Publik}

Cukup banyak definisi kebijakan yang telah dirumuskan para ahli dari berbagai bidang pengetahuan. Hal tersebut dapat dilihat dalam berbagai buku teks. Untuk keperluan praktis, ditawarkan suatu working definition yang diharapkan dapat mempermudah pengamatan atas fenomena kebijakan yang aktual, sebagai berikut: Kebijakan publik pada dasarnya adalah suatu keputusan yang dimaksudkan untuk mengatasi permasalahan tertentu, untuk melakukan kegiatan tertentu, atau untuk mencapai tujuan tertentu, yang dilakukan oleh instansi yang berkewengan dalam rangka penyelenggaraan tugas pemerintahan negara dan pembangunan. Dalam kehidupan administrasi negara, secara formal, keputusan tersebut lazimnya dituangkan dalam berbagai bentuk peraturan perundangundangan.

Bentuk instrumen kebijakan dan peraturan perundang-undangan yang dipilih tergantung pada substansi dan lingkup permasalahan, sifat kebijakan, luas dampak kebijakan, sistem ekonomi politik yang dianut, ada tidaknya keterkaitan dengan kebijakan perundang-undangan lainya, serta pada instansi pengambil keputusan. Oleh sebab itu, kebijakan publik dalam rangka penyelenggaraan negara merupakan suatu stratifikasi kebijakan, yang dari sudut manajemen dapat dibagi atas tiga kelompok, yaitu (a) kebijakan umum (strategic), (b) kebijakan manajerial, dan (c) kebijakan tehnis-oprasional; yang memiliki keterkaitan satu sama lain.

Secara konseptual, terdapat dua unsur penting dalam setiap substansi kebijakan yaitu (a) sejumlah tujuan kebijakan (ends, atau policy objectives. Yi) dan (b) sejumlah alat untuk mencapai tujuan (means, atau policy instruments. Xi). Saling hubungan antar (a) dan (b) dapat diekspresikan secara matematis sebagai $Y i=f$ (Xi); terdapat kemungkinan bahwa faktor Xi dipengaruhi pula oleh bebagai faktor lainya (Zi), dan seterusnya. Keseluruhaannya dapat digambarkan sebagai saling hubungan antar sejumlah faktor atau variabel,sehingga dapat merupakan sistem ekuasi yang cukup kompleks.

Sebagai keputusan yang dilakukan dalam rangka penyelenggaraan pemerintahan Negara,yang meliputi aspek-aspek kehidupan yang demikian luas, dan dilakukan oleh organisasi-organisasi pemerintahan yang cukup banyak, maka keputusan yang diambil oleh sesuatu organisasi pemerintah (Menteri Konordinator / Menteri / Menteri Negara / Gubernur / Bupati / Departemen / LPND / Perangkat Daerah) harus senantiasa memperhatikan keterkaitan, konsistensi, dan keterpaduannya dengan keputusan-keputusan atau kebijakan-kebijakan lainya, 


\section{Bayu Kharisma}

baik dalam unsur ends maupun means-nya. Hal ini dimaksudkan agar upaya-upaya yang dilakukan tersebut dapat mencapai sinergi dan kinerja yang optimal. Dari sudut sistem ekonomi politik, kebijakan dapat dipandang sebagai suatu bentuk intervensi yang dikeluarkan pemerintah untuk mempengaruhi mekanisme pasar agar proses perekonomian dalam masyarakat berlangsung sebagaimana diharapkan. Secara konstitusional, yang menjadi pedoman adalah tujuan nasional; secara aktual, yang menjadi pilihan adalah referensi partai politik yang mendominasi pemerintah. Dalam hubungan itu, birokrasi professional harus bisa menunjukan alternatif terbaik bagi kepentingan masyarakat luas dan selaras dengan cita-cita bangsa bernegara. Hal tersebut berlaku baik dalam penentuan ends atau pun means.

\subsubsection{Sistem Kebijakan}

Sehubungan dengan substansi, lingkup permasalahan, dan cakupan kebijakan yang demikian luas, ada baiknya permasalahan terlebih dahulu dikenali mengenai konsep sistem kebijakan (policy sistem). Sistem kebijakan adalah tatanan kelembagaan yang berperan atau merupakan "wahana dalam penyelenggaraan sebagian atau keseluruhan "proses kebijakan" (formulasi, implementasi dan evaluasi) yang mengakomodasikan kegiatan teknis maupun sosiopolitis serta saling berhubungan atau interaktive antar empat faktor dinamis (1) lingkungan kebijakan (2) pembuat dan pelaksana kebijakan (3) kebijakan itu sendiri, (4) kelompok sasaran.

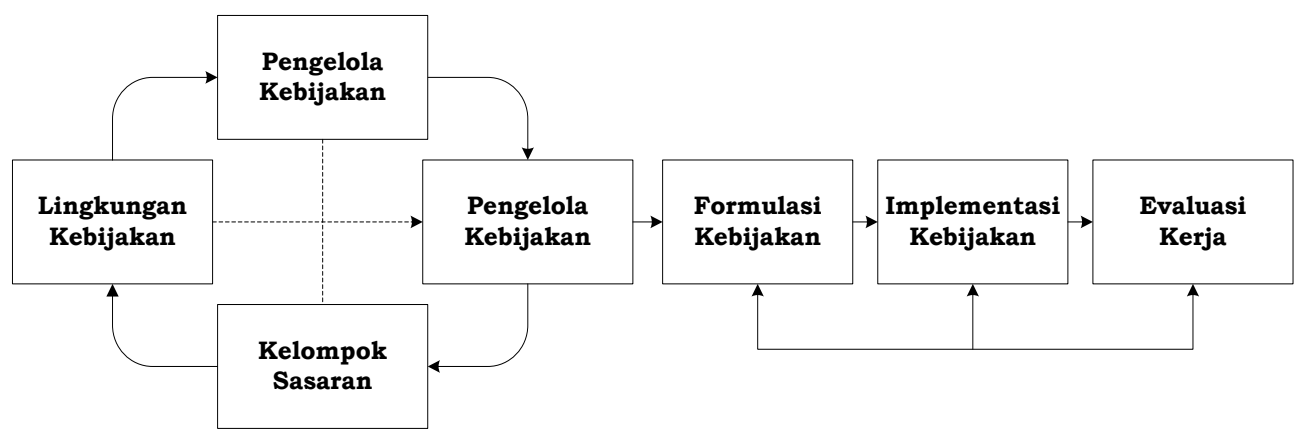

\section{Gambar 2.1. Saling Hubungan Sistem dan Proses Kebijakan}

Sebagaimana lazimnya suatu tatanan kelembagaan yang senantiasa mengandung dimensi nilai, maka sistem kebijakan terekspresikan dan berperan sebagai landasan, norma dan cita-cita (nilai-nilai dasar), tujuan dan aturan bermain (nilai-nilai instrumental) yang melekat pada dan merupakan karakteristik dari sistem tersebut. Keempat faktor dinamik yang merupakan unsur dari sistem kebijakan dan berperan dalam proses kebijakan di atas, masing-masing dirumuskan sebagai berikut:

(1) Lingkungan kebijakan (policy environment) adalah keadaan yang melatar belakangi atau peristiwa yang menyebabkan timbulnya "issues" kebijakan (policy issues), yang mempengaruhi dan dipengaruhi oleh para pelaku kebijakan dan oleh sesuatu kebijakan;

(2) Pembuat dan pelaksana kebijakan (policy maker and implementer), adalah orang atau sekelompok orang. Atau organisasi yang mempunyai "peranan tertentu" dalam proses kebijakan. Sebab mereka berada dalam posisi menentukan ataupun mempengaruhi baik dalam pembuatan kebijakan ataupun dalam tahap lainya, seperti pelaksanaan, pengawasan, dan penilaian atas hasil atau kinerja yang dicapai dalam perkembangan pelaksanaan kebijakan;

(3) Kebijakan itu sendiri (policy contents), yaitu keputusan atas sejumlah pilihan yang kurang lebih berhubungan satu sama lain yang dimaksudkan untuk menncapai sejumlah tujuan tertentu; dan 
(4) kelompok sasaran kebijakan (target groups), yaitu orang atau sekelompok orang, atau organisasi dalam masyarakat yang perilaku dan keadaannya ingin dipengaruhi oleh kebijakan bersangkutan.

Sistem kebijakan dirumuskan sebagai "the overall institutional paterrn within wich policies are made. Involves interrelationships among there elements: public policies, policy stakeholders, and policy environments" (William N. Dunn,1981). Perhatian terhadap posisi, peran interaktif, dan kondisi kelompok sasaran dalam proses kebijakan adalah penting, karena akan mempengaruhi ketepatan, efisiensi, efektivitas, dan kinerja kebijakan. Merekalah yang secara langsung akan dipengaruhi perilaku dan keadaannya; dan pada umumnya merekalah yang sesungguhnya merupakan konstituen, dan sumber legitimasi setiap kebijakan publik.

Pemerintah dan aparatur pemerintahan dapat dipandang sebagai stakeholder (pemangku kepentingan) yang diberi kewenangan dan tanggung jawab untuk mengambil keputusan terbaik bagi kepentingan publik (public interest). Oleh karena itu, adalah bijak apabila aspirasi mereka diperhatikan, dan langkah ini dijadikan sebagai kode etik yang terlembagakan untuk dijadikan parameter legitimasi suatu kebijakan. Berbicara mengenai kebijakan publik dan sistem kebijakan adalah berbicara mengenai peran pemerintah dan masyarakat dalam sistem penyelenggaraan Negara dalam berbagai dimensi kelembagaannya yang kompleks. Dinamika kelembagaan dalam proses kebijakan dipengaruhi oleh sistem politik ekonomi dan pemerintahan yang dianut, perkembangan lingkungan strategis, serta oleh pola manajemen pemerintahan yang dikembangkan.

\subsection{Indeks Pembangunan Manusia (IPM)}

IPM adalah merupakan indikator komposit tunggal yang digunakan untuk mengukur tingkat pencapaian pembangunan manusia yang sudah dilakukan di suatu Negara (wilayah). IPM atau Human Development Index (HDI) yang dikeluarkan oleh United Nations Development Program (UNDP) ini digunakan untuk mengukur Keberhasilan Kinerja dalam hal pembangunan manusia. Kkunci keberhasilan dalam pembangunan adalah semua yang terkait dengan kesejahteraan rakyat. Kata Kesejahteraan sendiri menurut terminologi dalam kamus Bahasa Indonesia mempunyai arti ketentraman, kesenangan hidup, kemakmuran dan keamanan. Selanjutnya, jika ingin kondisi ini dapat tercapai maka prasyarat utama yang perlu dilakukan adalah dengan meningkatkan mutu kehidupan individu/ perorangan melalui pembangunan manusia seutuhnya.

Kualitas pembangunan manusia yang telah dicapai oleh suatu wilayah dapat dilakukan dengan mengukur mutu pembangunan tersebut dengan menggunakan parameter dengan 3 (tiga) komponen antara lain; (1) Keberhasilan dalam kesehatannya yaitu dilihat dari kemampuan hidup secara fisik yaitu dengan melihat angka harapan hidup; (2) Kemampuan untuk merefleksikan keberhasilan pengembangan pendidikan dengan melihat angka melek huruf dan lama sekolah; (3) Besarnya barang dan jasa yang dapat disediakan oleh masyarakat bagi warganya yaitu dengan melihat paritas daya beli masyarakat.

Penjabaran dari 3 (tiga) komponen tersebut adalah sebagai berikut:(1) Angka Harapan Hidup; yaitu indikator yang mengukur longevity ( panjang umur) dari seseorang di suatu wilayah atau negara. Longevity ini bukan hanya upaya perorangan tetapi merupakan upaya masyarakat secara keseluruhan untuk menggunakan sumber daya yang ada sehingga dapat memperpanjang hidupnya.dalam menjaga sangat erat hubungannya dengan kesehatan Longevity ( panjang umur) ini erat kaitannya dengan kesehatan. Dapat dikatakan seseorang akan bertahan hidup lebih panjang apabila di selalu sehat, atau jika menderita sakit secepatnya dapat berobat untuk membantu mempercepat 


\section{Bayu Kharisma}

kesembuhannya.(2) Melek Huruf dan Lama Sekolah; yaitu indikator yang mengukur tingkat pendidikan penduduk dengan melihat seberapa jauh masyarakat di wilayah tersebut memanfaatkan sumber daya yang ada dalam upaya meningkatkan kecerdasan warganya. Indikator Melek Huruf diperoleh dari variabel kemampuan membaca dan menulis dan Indikator Lama Sekolah dihitung dari partisipasi sekolah, tingkat kelas yang sedang/pernah dijalani serta pendidikan tinggi yang ditamatkan.(3) Paritas Daya Beli ; Yaitu indikator yang mengukur tentang besarnya daya beli masyarakat di suatu wilayah atau negara. Dengan menggunakan indikator konsumsi riil yang disesuaikan. Sebagai catatan bahwa untuk UNDP dalam mengukur komponen digunakan indikator PDB per kapita.

Tabel 2.1.

Standar dan Pendekatan UNDP dalam Menghitung IPM

\begin{tabular}{|l|c|c|c|}
\hline \multicolumn{1}{|c|}{ Keterangan } & Nilai Maksimum & Nilai Minimum & Catatan \\
\hline $\begin{array}{l}\text { Angka Harapan } \\
\text { Hidup }\end{array}$ & 85 & 25 & Sesuai Standar UNDP \\
\hline Angka Melek Huruf & 100 & 0 & Sesuai Standar UNDP \\
\hline $\begin{array}{l}\text { Rata-Rata Lama } \\
\text { Sekolah }\end{array}$ & 15 & 0 & Sesuai Standar UNDP \\
\hline Konsumsi Per Kapita & 732.720 & 300.000 & $\begin{array}{l}\text { UNDP Menggunakan } \\
\text { PDRB perkapita Riil } \\
\text { yang disesuaikan }\end{array}$ \\
\hline
\end{tabular}

Sumber : UNDP, 2006

Meningkatnya status pembangunan manusia yang dilihat berdasarkan besaran IPM adalah salah satu penilaian kinerja peranan birokrasi pemerintahan sebagai penyelenggara negara atau wilayah. Klasifikasi status pembangunan manusia yang dapat digunakan adalah sebagai berikut:

Tabel 2.2.

Klasifikasi Status Pembangunan Manusia

\begin{tabular}{|c|c|}
\hline Nilai IPM & Status Pembangunan Manusia \\
\hline$<50$ & Rendah \\
\hline $50 \leq$ IPM $<66$ & Menengah bawah \\
\hline $66 \leq$ IPM $<80$ & Menengah atas \\
\hline$\geq 80$ & Tinggi \\
\hline
\end{tabular}

Sumber: UNDP, 2003

\section{METODOLOGI PENELITIAN}

Metode penelitian yang digunakan adalah metode survei. Data yang digunakan dalam penelitian ini adalah data primer dan sekunder. Data ini dapat diperoleh dari BPS, Bagian Perekonomian, Dinas Sosial, serta survey langsung ke lapangan. Melalui pengumpulan data primer dan sekunder dan observasi kemudian diinventarisir kebijakan ekonomi pemerintah Kota Bandung yang berkaitan dengan upaya peningkatan daya beli masyarakat. Studi ini menggunakan metode yang bersifat analisis deskriptif, yaitu suatu cara pengumpulan, penyusunan, dan perancangan, yang kemudian diinterpretasikan. Sedangkan pengertian deskriptif adalah menguraikan berbagai aspek yang berhubungan dengan studi ini dan yang akan mempengaruhi studi ini.

Teknik pengumpulan data dilaksanakan sesuai dengan jenis data yang diperlukan dalam studi, yaitu data primer dan data sekunder. Untuk pengumpulan jenis data yaitu sebagai berikut:

1. Data primer meliputi wawancara dengan para pelaku ekonomi, akademisi, pelaku usaha, masyarakat dan pimpinan dinas/instansi teknis terkait serta 
pemerintah daerah di tingkat kota Bandung.

2. Data sekunder meliputi data yang telah diperoleh dari Bappeda, dinas/instansi terkait; pemerintah daerah di tingkat kota Bandung dan provinsi Jawa Barat; BPS Pusat dan daerah serta lembaga-lembaga lain yang terkait.

Untuk memperoleh data primer akan ditetapkan sampel pelaku/aktor yang berkompeten dipilih sebagai responden, yaitu yang mengetahui permasalahan mengenai kebijakan ekonomi untuk meningkatkan daya beli masyarakat kota Bandung. Pengambilan sampel secara purposive convenience sampling dalam memilih sampel yaitu instansi daerah/dinas yang terkait, pelaku usaha dan masyarakat.

\subsection{Metode Analisis}

\subsubsection{Analisis SWOT}

Analisis SWOT terdiri dari analisis lingkungan internal dan eksternal. Analisis Lingkungan internal dilakukan dengan mengidentifikasi kekuatan dan kelemahan Pemerintah Kota Bandung berdasarkan kondisi internal Pemerintah Daerah Kota Bandung dalam meningkatkan daya beli masyarakat Kota Bandung. Misalnya, faktorfaktor yang dianalisis adalah kompetensi aparatur, anggaran yang dialokasikan untuk program-program penguatan daya beli masyarakat, program-program yang berhubungan dengan kondisi perekonomian dan program lainnya untuk menunjang keberlangsungan perekonomian Kota Bandung. Selanjutnya, analisis lingkungan eksternal dilakukan untuk mengentifikasi peluang dan ancaman yang dihadapi Pemerintah Daerah Kota Bandung dalam upaya meningkatkan daya beli masyarakat Kota Bandung. Aspek-aspek yang menjadi peluang dan ancaman terdiri dari faktorfaktor yang tidak dapat dikendalikan oleh Pemerintah Kota Bandung.

\subsubsection{Analytical Hierarchy Process (AHP)}

Alat analisis yang digunakan dalam penentuan evaluasi dan prioritas alternatif-alternatif program-program strategis bidang ekonomi dalam meningkatkan daya beli masyarakat di Kota Bandung melalui Analytical Hierarchy Process (AHP). Penggunaan AHP dimaksudkan mencari skala prioritas dari berbagai alternatif kebijakan berdasarkan pandangan dan kepentingan para stakeholder. Peralatan utama dari model ini adalah sebuah hirarkhi fungsional dengan input utamanya persepsi manusia. Pada dasarnya AHP adalah metode yang memecah suatu masalah yang kompleks dan tidak terstruktur ke dalam kelompokkelompoknya, mengatur kelompok-kelompok tersebut ke dalam suatu hirarkhi; memasukkan nilai numerik sebagai penganti persepsi manusia dalam melakukan perbandingan relatif dan akhirnya dengan suatu sintesa ditentukan elemen mana yang mempunyai prioritas tertinggi atau dengan kata lain, prinsip metode AHP adalah memberikan bobot tiap faktor, variabel, dan indikator dengan perbandingan antar faktor, variabel, indikator satu dengan lainnya. Bobot yang lebih besar dari suatu indikator, menunjukkan indikator yang lebih penting dibandingkan indikator lainnya dalam mengevaluasi Program - Program Strategis Pemerintah Kota Bandung di Bidang Ekonomi dalam upaya penguatan dan peningkatan kemampuan daya beli masyarakat. Dalam menyelesaikan persoalan dengan menggunakan model AHP perlu dilakukan beberapa langkah antara lain :

- Memecahkan persoalan utuh menjadi unsur-unsurnya (Decomposition)

- Penilaian Perbandingan Kepentingan (Comparative Judgment)

- Melakukan Sintesis Prioritas (Synthesis of Priority)

- Menentukan Konsistensi Logis (Logical Consistency)

\section{Memecahkan persoalan utuh menjadi unsur-unsurnya (Decomposition)}




\section{Bayu Kharisma}

Setelah persoalan didefinisikan dengan baik, maka perlu dilakukan dekomposisi, yaitu memecah persoalan yang utuh menjadi unsur-unsurnya. Apabila ingin mendapatkan hasil yang akurat, maka pemecahan juga dilakukan terhadap unsur-unsurnya sampai tidak mungkin dilakukan pemecahan lebih lanjut, sehingga didapatkan beberapa tingkatan dari persoalan tersebut.

Dekomposisi mencakup tiga proses yang berurutan dan saling berhubungan, yaitu identifikasi level dan elemen, definisi konsep dan formulasi pertanyaan. Langkah pertama adalah mengidentifikasikan level-level dan elemen-elemen yang akan ditempatkan dalam suatu level. Kemudian semua level dan elemen-elemen didefinisikan dan dipakai dalam tahap formulasi pertanyaan. Apabila dalam pembuatan hirarki menghadapi kesulitan dalam membuat pertanyaan-pertanyaan tersebut, maka level-level dan konsep-konsep harus direvisi dan dimodifikasi. Proses penyusunan hirarki sebenarnya merupakan proses iterasi semana konsep-konsep, pertanyaan-pertanyaan dan jawaban-jawabannya menentukan elemen dan level dalam suatu hirarki. Ketidakjelasan atau kesalahan dalam proses menjawab pertanyaan akan membuat para pengambil keputusan memilih kriteria atau alternatif yang salah. Karena itu semua pertanyaan seharusnya dapat dijawab dan konsisten dengan informasi yang ada. Dengan memperhatikan langkah-langkah tersebut, maka dalam suatu model AHP, dekomposisi sebenarnya merupakan bagian terpenting karena disinilah validitas dan keampuhan suatu model dapat diuji. Bentuk hirarki yang kurang sesuai akan menghasilkan suatu model yang kurang bermanfaat, meskipun hirarki tersebut diisi oleh seorang ekspert yang memang berkompeten dibidangnya.

Proses penyusunan hirarki dapat dijelaskan sebagai berikut. Pertama adalah mengidentifikasikan tujuan keseluruhan pembuatan hirarki atau lazim disebut dengan "goal". Setelah itu, menentukan kriteria-kriteria yang diperlukan atau kirakira sesuai dengan tujuan keseluruhan tersebut. Kriteria ini pada umumya terdiri dari syarat-syarat atau keadaan yang kiranya dapat menunjang tercapainya sebuah "goal" dan biasanya masih bersifat umum (general). Sejalan dengan hal tersebut, maka perlu dipertimbangkan kemungkinan penambahan sub-sub kriteria di bawah setiap kriteria. Subkriteria merupakan penjabaran lebih detail dari kriteria yang masih bersifat umum tersebut. Terakhir, melakukan identifikasi alternatif-alternatif yang akan dievaluasi di bawah sub kriteria. Apabila subkriteria-subkriteria yang ada dirasakan terlalu luas, maka segera menambahkan sebuah level di atas alternatifalternatif yang mengidentifikasikan atribut-atribut dari alternatif-alternatif dalam proses evaluasi.

Apabila penting tidaknya atribut-atribut tersebut dapat ditentukan dalam kaitannya dengan subkriteria, maka penyusunan hirarki dapat dikatakan selesai. Selain itu, jika atribut-atribut tersebut tidak dapat dijelaskan, maka perlu ditambahkan lagi suatu level di atas atribut-atribut untuk evaluasi tersebut. Penambahan level-level baru harus terus dilakukan sampai didapatkan hubungan yang sesuai dalam kaitannya dengan salah satu elemen di level atasnya. Keunggulan-keunggulan dalam penyusunan hirarki antara lain sebagai berikut :

- Menggambarkan sistem yang dapat digunakan untuk menggambarkan bagaimana perubahan prioritas pada tingkat di atas akan mempengaruhi tingkat dibawahnya.

- Memberikan informasi yang sangat terperinci tentang struktur dan fungsi sistem pada tingkat yang rendah dan memberikan gambaran mengenai pelaku dan tujuan pada tingkat di atasnya. Batasan dari elemen di suatu tingkat paling tidak disajikan pada level berikutnya.

- Sistem secara alamiah merupakan suatu hirarki.

- Stabil, dimana sedikit perubahan mempunyai sedikit pengaruh dan fleksibel dimana tambahan pada hirarki yang sudah terstruktur dengan baik tidak akan merusak kinerjanya. 
Aplikasi AHP dalam studi ini adalah melakukan evaluasi dan menetapkan prioritas terhadap program-program yang merupakan derivasi dari kebijakan ekonomi Pemerintah Daerah Kota Bandung. Selanjutnya, kriteria yang dijadikan pertimbangan dalam studi ini didasarkan pada faktor-faktor internal dan eksternal yang dapat mempengaruhi meningkatkan daya beli masyarakat Kota. Sementara itu, yang menjadi aktor-aktor yang berperan penting dalam daya beli masyarakat Kota Bandung ada kajian ini adalah instansi daerah yang terkait, pelaku usaha dan pihak masyarakat.

\section{Penilaian Perbandingan Kepentingan (Comparative Judgment)}

Prinsip ini berarti membuat penilaian tentang kepentingan relatif dari dua elemen pada suatu tingkat tertentu dalam kaitannya dengan tingkat diatasnya. Penilaian ini merupakan inti dari AHP, karena hal tersebut akan berpengaruh terhadap prioritas elemen-elemen. Hasil dari penilaian ini akan tampak lebih jelas apabila diperlihatkan dalam bentuk matriks yang dinamakan matriks pairwise comparison. Agar diperoleh skala yang bermanfaat ketika membandingkan dua elemen, maka seorang responden yang akan memberikan jawaban perlu pengertian yang komprehensif dan menyeluruh tentang elemen-elemen yang dibandingkan dan relevansinya terhadap kriteria atau tujuan yang dipelajari. Dalam penyusunan skala kepentingan ini, digunakan beberapa ukuran 1 sampai dengan 9. Skala perbandingan ini disebut dengan skala fundamental yang diturunkan berdasarkan riset psikologis Saaty atas kemampuan individu dalam membuat suatu perbandingan secara berpasangan terhadap beberapa elemen yang diperbandingkan.

Tabel. 4.3 Skala Perbandingan Berpasangan Analitical Hierarchy Process

\begin{tabular}{|c|c|c|}
\hline Tingkat & Definisi & Keterangan \\
\hline 1 & $\begin{array}{l}\text { Kedua elemen adalah sama } \\
\text { penting }\end{array}$ & $\begin{array}{l}\text { Kedua elemen memiliki pengaruh } \\
\text { sama }\end{array}$ \\
\hline 3 & $\begin{array}{l}\text { Elemen yang satu sedikit lebih } \\
\text { penting daripada yang } \\
\text { lainnya }\end{array}$ & $\begin{array}{l}\text { Penilaian sedikit lebih memihak } \\
\text { pada salah satu elemen } \\
\text { disbanding pasaganya (moderat) }\end{array}$ \\
\hline 5 & $\begin{array}{lcc}\text { Elemen } & \text { yang satu } & \text { lebih } \\
\text { penting } & \text { daripada } & \text { yang } \\
\text { lannya } & & \\
\end{array}$ & $\begin{array}{l}\text { Salah satu elemen sangat } \\
\text { berpengaruh dan dominasinya } \\
\text { tampak secara nyata }\end{array}$ \\
\hline 7 & $\begin{array}{l}\text { Elemen yang satu jelas sangat } \\
\text { penting daripada elemen } \\
\text { yang lainnya }\end{array}$ & $\begin{array}{l}\text { Bukti bahwa salah satu elemen } \\
\text { sangat penting daripada } \\
\text { pasangannya adalah sangat jelas }\end{array}$ \\
\hline 9 & $\begin{array}{l}\text { Elemen yang satu mutlak } \\
\text { sangat penting daripada } \\
\text { elemen yang lainnya }\end{array}$ & $\begin{array}{l}\text { Bukti bahwa salah satu elemen } \\
\text { sangat penting daripada } \\
\text { pasangannya adalah sangat jelas }\end{array}$ \\
\hline $2,4,6,8$ & $\begin{array}{l}\text { Nilai tengah di antara dua } \\
\text { perbandingan } \\
\text { berdekatan }\end{array}$ & $\begin{array}{l}\text { Nilai ini diberikan jika terdapat } \\
\text { keraguan di antara kedua } \\
\text { penilaian yang berdekatan }\end{array}$ \\
\hline $\begin{array}{c}\text { Kebalikann } \\
\text { ya } \\
\text { (reciprocal) }\end{array}$ & $\begin{array}{l}\text { Jika elemen x mempunyai sa } \\
\text { dibandingkan dengan elemen } \\
\text { kebalikan bila dibandingkan de }\end{array}$ & $\begin{array}{l}\text { lah satu nilai di atas pada saat } \\
\text { y, maka elemen y mempunyai nilai } \\
\text { hgan elemen } x\end{array}$ \\
\hline
\end{tabular}

Sumber : Saaty, 1998

Dalam penilaian kepentingan relatif dua elemen berlaku aksioma reciprocal comparison. Artinya, jika elemen $x$ dinilai 2 kali lebih penting dibanding $y$, maka elemen y harus sama dengan $1 / 2$ kali pentingnya dibanding elemen $x$. Disamping itu, perbandingan dua elemen yang sama akan menghasilkan angka 1. Artinya, sama penting. Jika terdapat $n$ elemen, maka akan diperoleh matriks pairwise comparison berikuran $\mathrm{n} \times \mathrm{n}$. Banyaknya penilaian yang diperlukan dalam menyusun matriks ini 


\section{Bayu Kharisma}

adalah $n(n-1) / 2$ karena matriksnya reciprocal dan elemen diagonal sama dengan 1. Skala 1 sampai dengan 9 tersebut dianggap terbaik karena tingkat akurasinya yang tinggi. Hal ini ditunjukkan dengan RMS (Root Mean Squares) dan MAD (Mean Absolute Deviation) pada berbagai permasalahan.

\section{Sintesis Prioritas (Synthesis of Priority)}

Setelah matriks perbandingan untuk sekelompok elemen selesai dibentuk, maka langkah selanjutnya adalah mengukur bobot prioritas setiap elemen tersebut dengan dasar persepsi seorang ekspert yang telah dimasukkan dalam matriks tersebut. Dari setiap matriks pairwise comparison kemudian dicari eigenvectornya untuk mendapatkan local priority. Karena matriks pairwise comparison terdapat pada setiap tingkat, maka untuk medapatkan global priority harus dilakukan sintesa di antara local priority. Prosedur melakukan sintesa berbeda menurut bentuk hirarki. Pengurutan elemen-elemen menurut kepentingan relatif melalui prosedur sintesa dinamakan prioriy setting.

Salah satu cara yang dapat dipakai untuk mengukur bobot prioritas seriap elemen adalah dengan menjumlahkan angka-angka setiap kolom dan kemudian membentuk resiprokal (bentuk kebalikan) dari jumlah-jumlah tersebut. Agar total dari resiprokal jumlah setiap kolom sama dengan satu, maka membagi resiprokal jumlah setiap kolom dengan totalnya sehingga didapatkan prioritas akhir setiap elemen. Cara ini dianggap lebih baik dari segi operasi perhitungan terutama keakuratannya tetapi tetap belum memecahkan masalah utama yaitu belum menjelaskan kaitan antara elemen yang satu dengan yang lainnya dalam perhitungan. Usaha untuk memasukkan kaitan antara elemen yang satu dengan yang lain dalam menghitung bobot prioritas secara sederhana dapat dilakukan dengan cara berikut. Pertama, membagi setiap angka (skala) dalam suatu kolom dengan jumlah tersebut dan lakukan hal yang sama untuk setiap kolom. Kemudian angka (skala) baru yang dihasilkan dari pembagian tersebut dijumlahkan menurut baris. Setlah itu dicari total dari jumlah elemen setiap baris dan kemudian seperti cara lainnya, yaitu dilakukan pembagian dari jumlah setiap baris terhadap totalnya agar didapatkan prioritas terakhir setiap elemen dengan total bobot prioritas sama dengan satu. Proses yang dilakukan untuk membuat total bobot prioritas sama dengan satu biasa disebut dengan proses normalisasi.

\section{Konsistensi Logis (Logical Consistency)}

Konsistensi memiliki dua makna. Pertama adalah bahwa obyek-obyek yang serupa dapat dikelompokkan sesuai dengan keseragaman dan relevansinya. Contohnya, anggur dan kelereng dapat dikelompokkan dalam himpunan yang seragam jika bulat merupakan kriterianya, tetapi hal tersebut tidak dapat dikelompokkan sebagai himpunan yang seragamam jika rasa sebagai kriterianya. Arti kedua adalah menyangkut tingkat hubungan antara obyek-obyek yang didasarkan ada kriteria tertentu. Contohnya jika manis sebagai kriteria. Apabila coklat dinilai $4 \mathrm{X}$ lebih manis daripada sirop dan sirop $3 \times$ lebih manis dibandingkan madu, maka seharusnya coklat lebih manis $8 x$ dibandingkan dengan madu.

Pengukuran konsistensi dalam model AHP dilakukan dalam dua tahap. Tahap pertama adalah mengukur konsistensi setiap matriks perbandingan dan tahap kedua mengukur konsistensi keseluruhan hirarki. Pengertian konsistensi itu sendiri adalah jenis pengukuran yang tak dapat terjadi begitu saja atau dengan kata lain mempunyai syarat tertentu. Suatu matriks, misalnya dengan tiga unsur (i,j dan k) dan setiap perbandingan dinyatakan dengan a, akan konsisten $100 \%$ apabila memenuhi syarat sebagai berikut :

$$
a_{i j} \cdot a_{j k}=a_{i k}
$$

Dengan syarat tersebut, maka matriks $\mathrm{A}$ berikut ini dapat dinyatakan konsisten karena :

$$
\left.i \quad \begin{array}{lll}
i & j & k \\
1 & 4 & 2
\end{array}\right)
$$




$\begin{array}{llll}j & 1 / 4 & 1 & 1 / 2 \\ k & 1 / 2 & 2 & 1\end{array}$

$$
\begin{aligned}
& a_{i j} \cdot a_{j k}=a_{i k} \longrightarrow 4 \cdot 1 / 2=2 \\
& a_{\mathrm{ik}} \cdot a_{\mathrm{kj}}=a_{\mathrm{ij}} \longrightarrow 2.2=4 \\
& a_{\mathrm{ik}} \cdot a_{\mathrm{ki}}=\mathrm{a}_{\mathrm{ji}} \longrightarrow 1 / 2 \cdot 1 / 2=1 / 4
\end{aligned}
$$

Tahap pertama, adalah mengukur konsistensi setiap matriks perbandingan. Pengukuran konsistensi dari suatu matriks itu sendiri didasarkan atas suatu eigenvalue maksimum. Dengan eigenvalue maksimum, inkonsistensi yang biasa dihasilkan matriks perbandingan dapat diminimumkan. Rumus dari indeks konsistensi (Cl) adalah sebagai berikut :

$$
\mathrm{CI}=\frac{\lambda_{\text {maks }}-\mathrm{n}}{\mathrm{n}-1}
$$

dimana :

$\lambda_{\text {maks }}=$ Nilai eigenvalue maksimum

$\mathrm{n} \quad=$ Ukuran matriks

$\mathrm{Cl} \quad=$ Indeks Konsistensi

Eigenvalue maksimum suatu matriks tidak akan lebih kecil dari nilai $n$ sehingga tidak mungkin ada nilai $\mathrm{Cl}$ yang negatif. Makin dekat eigenvalue maksimum dengan besarnya matriks, makin konsisten matriks tersebut dan apabila sama besarnya, maka matriks tersebut konsisten $100 \%$ atau inkonsisten $0 \%$. Sedangkan untuk menghitung rasio konsistensi (CR) dapat dilakukan dengan rumus :

$$
\mathrm{CR}=\mathrm{CI} / \mathrm{RI}
$$

dimana :

$\mathrm{Cl}=$ Indeks konsistensi

$\mathrm{RI}=$ Nilai indeks acak (random value)

$\mathrm{CR}=$ Rasio konsistensi

Batasan diterima rasio konsistensi suatu matriks adalah $10 \%$ ke bawah. Artinya, bahwa tingkat inkonsistensi di bawah $10 \%$ masih bisa diterima. Lebih dari itu harus ada revisi penilaian karena tingkat inkonsistensi yang terlalu besar dapat menjurus pada suatu kesalahan.

Tabel 3.4. Nilai Indeks Acak (RI)

\begin{tabular}{|c|c|c|c|c|c|c|c|c|c|c|c|c|}
\hline $\mathbf{n}$ & $\mathbf{1}$ & $\mathbf{2}$ & $\mathbf{3}$ & $\mathbf{4}$ & $\mathbf{5}$ & $\mathbf{6}$ & $\mathbf{7}$ & $\mathbf{8}$ & $\mathbf{9}$ & $\mathbf{1 0}$ & $\mathbf{1 1}$ & $\mathbf{1 2}$ \\
\hline $\mathrm{RI}$ & 0 & 0 & 0,58 & 0,90 & $\begin{array}{c}1,1 \\
2\end{array}$ & 1,24 & 1,32 & $\begin{array}{c}1,4 \\
1\end{array}$ & 1,45 & 1,49 & 1,51 & 1,48 \\
\hline
\end{tabular}

Sumber : Saaty, Thomas L. 1989.

Tahap kedua, mengukur konsistensi keseluruhan hirarki. Secara keseluruhan bahwa hirarki pun harus konsisten. Untuk menguji konsistensi hirarki digunakan hasil indeks konsistensi dan prioritas relatif setiap matriks perbandingan berpasangan pada tingkat hirarki tertentu. Rumus yang digunakan untuk menguji konsistensi hirarki adalah sebagai berikut :

dimana :

$$
C R H=M / \bar{M}
$$

$M=\mathrm{Cl}$ level II +Bobot prioritas II.Cl level III 


\section{Bayu Kharisma}

$\overline{\mathrm{M}}=$ RI level II + bobot prioritas II. RI level III

$\mathrm{RI}=$ Indeks Random

Hasil penilaian hirarki secara keseluruhan dapat diterima jika mempunyai rasio konsistensi (CRH) lebih kecil dari $10 \%$.

\section{PEMBAHASAN HASIL PENELITIAN}

Ada beberapa langkah atau upaya yang dapat dilakukan Pemerintah Daerah Kota Bandung dalam mengevaluasi kebijakan ekonomi yang dituangkan dalam berbagai bentuk program dalam rangka meningkatkan daya beli masyarakat Kota Bandung. Langkah pertama, melihat potensi dan permasalahan dengan menggunakan analisis SWOT (strengths, weaknesses, opportunities, threats). Langkah kedua, kebijakan pengelolaan keuangan daerah Pemerintah Daerah Kota Bandung yang berkaitan dengan program-program peningkatan daya beli masyarakat. Langkah ketiga, untuk melakukan evaluasi kebijakan ekonomi yang dituangkan dalam berbagai program dilakukan analisis AHP dan menghubungkannya dengan indikator makroekonomi daerah (regional macroeconomic indicator).

\subsection{Analisis SWOT (strengths, weaknesses, opportunities, threats)}

Analisis SWOT ditujukan untuk melihat potensi dan permasalahan secara internal dan eksternal mengenai faktor-faktor yang mempengaruhi daya beli masyarakat Kota Bandung. Selanjutnya dapat diperoleh gambaran jelas mengenai kekuatan dan peluang yang dapat dimanfaatkan secara optimal oleh Pemerintah Daerah Kota Bandung berkaitan dengan upaya meningkatkan daya beli masyarakat Kota Bandung yang disesuaikan dengan kelemahan dan ancaman yang ada.

\subsubsection{Identifikasi dan Deskripsi Fakłor Internal Daya Beli Masyarakat Kota Bandung} a. Faktor Kekuatan (strengths)

1. Komitmen Kuat dari Pemerintah Daerah Kota Bandung untuk Meningkatkan Daya Beli Masyarakat Kota Bandung

Dalam hal ini, pemerintah mencurahkan berbagai potensi daerah yang dimiliki untuk menggerakkan perekonomian masyarakat dan membuat perencanaan serta langkah-langkah operasionalnya, khususnya dalam upaya meningkatkan daya beli masyarakat Kota Bandung. Dengan komitmen yang kuat dari kebijakan ekonomi yang dikeluarkan oleh Pemerintah Kota Bandung, diharapkan akan mendongkrak daya beli masyarakat melalui peningkatan kegiatan ekonomi yang mampu menyerap tenaga kerja dan meningkatkan pendapatan masyarakat. Komitmen kuat Pemerintah Daerah Kota Bandung secara implisit tertuang dari Visi Kota Bandung dalam jangka panjang tahun 2004-2008 yaitu "Terwujudnya Kota Bandung Sebagai Kota Jasa yang Bermartabat (Bersih, Makmur, Taat dan Bersahabat)" . Makna yang tertuang dari visi tersebut adalah Kota Bandung sebagai Kota Jasa dapat memberikan kemakmuran terhadap masyarakatnya. Visi tersebut diwujudkan melalui kebijakan ekonomi yang mengupayakan peningkatan kegiatan perekonomian kota yang berbasiskan potensi daerah yang dituangkan dalam berbagai program strategis. Selain itu, bukti komitmen kuat lainnya dari pemerintah daerah Kota Bandung terhadap penguatan daya beli masyarakat diwujudkan dengan adanya program bantuan walikota khusus bidang kemakmuran (Bawaku Makmur) yang merupakan dana hibah yang diberikan oleh pemerintah untuk dapat digunakan untuk menunjang ekonomi yang produktif, dengan harapan akan meningkatkan pendapatan dan daya beli para penerima bantuan tersebut.

2. Program-Program Pemerintah Daerah Kota Bandung Sudah Mencakup Semua Sektor 
Program Pemerintah Daerah Kota Bandung melakukan kebijakan untuk peningkatan daya beli tidak hanya dituangkan dalam program yang terkait langsung dengan bidang ekonomi saja tetapi juga meliputi bidang lainnya yang secara tidak langsung mampu mendorong peningkatan aktivitas ekonomi sehingga mampu menaikkan daya beli masyarakat. Program-program tersebut terdiri dari 8 (delapan) program, yaitu : 1) Program Pembinaan dan Pengembangan Usaha Industri, 2) Program Pembinaan dan Pengembangan Usaha Perdagangan, 3) Program Pembinaan dan Pengembangan Usaha Koperasi, 4) Program Pembinaan Usaha Kecil, 5) Program Peningkatan Investasi Kota, 6) Program Pembinaan Pemasaran Parawisata, 7) Program produk keparawisataan dan 8) Program Pengembangan Agribisnis.

3. Target dan Sasaran Sudah Sangat Jelas

Target dan sasaran program sudah ditentukan sangat jelas sehingga memudahkan pelaksanaan program-program serta pencapaian tujuan dalam penguatan dan peningkatan daya beli masyarakat Kota Bandung. Pemerintah Kota Bandung telah menetapkan target kebijakan peningkatan daya beli dengan mendorong pergerakan sektor riil, antara lain melalui Program Bawaku Makmur yang sasarannya sudah jelas yaitu kelompok masyarakat, usaha mikro, kecil dan menengah.

4. Dukungan Secara Politis dari Dewan Perwakilan Rakyat Daerah (DPRD) Kota Bandung terhadap Kebijakan Pemerintah Daerah Dalam Rangka Peningkatan Daya Beli Masyarakat

Kebijakan Pemerintah Daerah Kota Bandung yang dtujukan untuk meningkatkan daya beli masyarakat perlu mendapatkan legalitas dan dukungan politik dari lembaga legislatif yaitu DPRD. Aspek legalitas kebijakan merupakan dukungan politis dari dewan. Kebijakan kemudian akan dapat dijalankan oleh pemerintah dengan pengawasan legislatif.

5. Target Waktu Pencapaian Prioritas Program Sudah Ditetapkan

Kejelasan target waktu pencapaian suatu program akan memandu pelaksanaan program sesuai rencana. Setiap program yang ditetapkan pemerintah kota telah ditetapkan target waktu pencapaian tujuannya. Antara lain prioritas program kemakmuran dengan menetapkan laju pertumbuhan ekonomi (LPE) Kota Bandung 2008 sebesar 11\% (kebijakan pengembangan ekonomi Kota Bandung dalam Perda No. 6 Tahun 2004) dalam upaya mendongkrak daya beli masyarakat Kota Bandung. Selain itu, adanya program bantuan walikota khusus bidang kemakmuran yaitu Bawaku Makmur memiliki tahapan-tahapan yang sistematis dalam pelaksanaannya berdasarkan pencairan bagi pihak-pihak penerimanya.

6. Koordinasi Antara SKPD Dalam Pelaksanaan Program Ekonomi Sudah Berjalan dengan Baik

Koordinasi antar SKPD diwujudkan antara lain dalam bentuk urun rembuk dalam pengambilan keputusan mengenai cara pelakasanaan dan pencapaian tujuan program. Adanya koordinasi yang baik antar SKPD memungkinkan programprogram pemerintah kota tidak tumpang tindih dan tidak memboroskan anggaran sehingga pelaksanaannya lebih efektif dan efisien.

b. Faktor Kelemahan (weaknesses)

1. Sosialisasi Program-Program Kepada Masyarakat yang Berkaitan dengan Penguatan Daya Beli Dirasakan Masih Lemah

Efektif atau tidaknya suatu program antara lain sangat dipengaruhi oleh sosialisasi terhadap program tersebut. Sosialisasi program yang berkaitan dengan penguatan daya beli harus ditempuh oleh Pemerintah Daerah Kota Bandung dengan memperkenalkan program - program tersebut kepada masyarakat dan mengajak masyarakat untuk berpartisipasi aktif. Selama ini, program-program pemerintah daerah Kota Bandung yang berkaitan dengan peningkatan daya beli dirasakan masih lemah. Hal ini tercermin dengan masih 


\section{Bayu Kharisma}

banyaknya masyarakat yang belum mengetahui program pemerintah dalam penguatan daya beli, misalnya program bantuan walikota khusus bidang kemakmuran yaitu Bawaku Makmur (Tribun Jawa Barat, 2008).

2. Standar Pelayanan Minimum (SPM) Belum Sepenuhnya Terlaksana dengan Baik Standar Pelayanan Minimum (SPM) merupakan acuan untuk mengukur kualitas dan kuantitas pelayanan publik yang diberikan pemerintah daerah. Dengan demikin, SPM juga merupakan ukuran untuk melihat kinerja pemerintah daerah. SPM terkait dengan pelaksanaan urusan wajib yang sebenarnya merupakan pelayanan dasar, seperti pendidikan, kesehatan dan peningkatan standar hidup layak. Ketidakmampuan pemerintah daerah menjalankan SPM akan mengakibatkan ekonomi biaya tinggi (high cost economy). Hal ini dikarenakan masyarakat harus membayar mahal pelayanan publik yang seharusnya dapat mereka dapatkan dengan cuma - cuma atau dengan harga yang murah. Pada akhirnya biaya- biaya ekonomi yang dikelvarkan anggota masyarakat akan mempengaruhi daya beli masyarakat.

3. Kemampuan Alokasi Anggaran Pemerintah Daerah Kota Bandung yang Berkaitan Dengan Program Peningkatan Daya Beli Masih Rendah

Keberhasilan suatu program Pemerintah sangat berkaitan erat dengan besar atau kecilnya anggaran yang dialokasikan dan disitribusikan terhadap program tersebut. Berdasarkan informasi mengenai belanja daerah Kota Bandung selama tahun Anggaran 2003-2008, Pemerintah Daerah kota Bandung lebih besar mengalokasikan anggarannya pada belanja tidak langsung yang menitikberatkan pada belanja aparatur daerah, dimana alokasi penggunaannya lebih diarahkan untuk membiayai kebutuhan-kebutuhan Pemerintah Kota Bandung yang bersifat internal guna menjalankan roda pemerintahan secara berkesinambungan dan membiayai kebutuhan Perangkat Daerah yang memberikan pelayanan kesehatan, Perangkat Kelurahan serta bantuan pelaksanaan program dan kegiatan organisasi kemasyarakatan dan organisasi profesi yang ada di Kota Bandung dan bukan pada upaya peningkatan daya beli masyarakat.

4. Ketersediaan dan Kemampuan Sumber Daya Manusia (aparatur) yang Berkaitan langsung dengan Program Daya Beli Masih Terbatas

Pemerintah Kota Bandung selama ini memiliki sumber daya manusia (aparatur) yang terbatas, khususnya yang terkait langsung program-program peningkatan daya beli masyarakat. Keterbatasan ini diatasi dengan cara mengangkat tenaga honorer dan merekrut CPNS baru melelui mekanisme perekrutan lokal. Dari segi kinerja, aparatur Pemkot saat ini masih perlu ditingkatkan. Semakin banyak aparatur maka akan semakin mudah program-program dijalankan. Demikian pula semakin tinggi profesionalisme aparatur semakin tinggi pula outcome yang diperoleh dari pelaksanaan program- program Pemerintah Daerah Kota Bandung.

5. Lemahnya Kemampuan Monitoring dan Evaluasi Terhadap Program Penguatan Daya Beli

Monitoring dan evaluasi merupakan fungsi yang sangat penting dalam setiap pelaksanaan program pemerintah kota. Fungsi monitoring adalah memonitor pelaksanaan program yang sedang dilaksanakan supaya tetap tidak terjadi penyimpangan dari rencana. Sementara evaluasi yang dilakukan secara berkala yang bertujuan untuk menilai pekerjaan sedang berjalan dan mengoreksi kesalahan yang terjadi. Berdasarkan suvei terhadap penerima bantuan program Bawaku, masih banyak peneriman bantuan tersebut ternyata pihak yang tidak berhak menerimannya dan banyak digunakan untuk kegiatan yang bersifat konsumtif bukan untuk modal kerja (Tribun Jawa Barat, 2008). Hal ini disebabkan antara lain karena lemahnya monitoring dan evaluasi terhadap program tersebut.

6. Ketersediaan Sistem Informasi dan Database 
Sistem informasi dapat digunakan untuk melukan pengendalian dan pengawasan terhadap pelaksanaan program-program ekonomi yang berkaitan dengan peningkatan daya beli. Sistem informasi meliputi juga management data base system. Semakin baik sistem informasi maka semakin efektif pengawasan program. Semakin tertata data base maka semakin mudah mengidentifikasi sasaran program dan menganalisis pelaksanaan program. Berdasarkan suvei terhadap penerima bantuan program Bawaku, masih banyak peneriman bantuan tersebut ternyata pihak yang sebenarnya tidak berhak untuk menerimannya. Hal ini disebabkan masih lemahnya ketersediaan informasi mengenai masyarakat peneriman bantuan tersebut. Seharusnya Bawaku Makmur diberikan kepada masyarakat yang memenuhi kualifikasi persyaratan dan ketentuan serta melalui proses survei dan seleksi yang transparan dan objektif (sesuai dengan Peraturan Walikota Bandung Nomor 321 Tahun 2007 tentang Petujuk Teknis Penyaluran/Pemberian program Bantuan Peningkatan Kemakmuran). Adapun secara spesifik sasaran penerima dana hibah adalah sebagai berikut: 1)Kelompok masyarakat atau perorangan yang melakukan perintisan usaha; 2) Pelaku Usaha Kecil dan Menengah baik kelompok maupun perorangan di Bidang Jasa, Produksi, Industri dan Perdagangan dan 3) Koperasi dengan bidang usaha : Simpan Pinjam, Konsumen, Produsen dan Aneka Usaha.

\subsubsection{Identifikasi dan Deskripsi Faktor Eksternal Daya Beli Masyarakat Kota Bandung}

a. Faktor Peluang (opportunities)

1. Kebijakan Pemerintah Pusat Mengenai Konversi Minyak Tanah ke LPG

Kebijakan konversi minyak tanah ke LPG merupakan upaya pemerintah untuk mengurangi ketergantungan masyarakat terhadap BBM (khususnya minyak tanah) yang kini kapasitas produksinya sudah semakin menurun, ditengah permintaan masyarakat yang masih tetap tinggi. Selain itu, kebijakan konversi tersebut dilakukan oleh Pemerintah Pusat dalam upaya mengantisipasi melambungnya harga minyak mentah dunia yang secara langsung mempengaruhi harga minyak di Indonesia dan pengeluaran pemerintah untuk subsidi BBM meningkat. Dengan demikian, tidak bergantungnya dan mudahnya dalam perolehan gas LPG dibandingkan minyak bumi, khususnya minyak tanah disinyalir merupakan peluang bagi masyarakat, khususnya Kota Bandung dalam meningkatkan daya beli.

2. Muara Pembangunan Nasional adalah Kesejahteraan Rakyat

Pembangunan nasional memiliki tujuan yang sama dengan pembangunan yang dilaksanakan di daerah, yaitu mewujudkan masyarakat sejahtera adil dan makmur. Masyarakat sejahtera berarti mampu memenuhi kebutuhan dasar baik sandang, pangan, maupun papan secara layak. Dengan adanya kemampuan dalam memenuhi kebutuhan dasar yang baik secara tidak langsung dapat menunjukkan bahwa daya beli masyarakat secara relatif cukup baik. Dengan demikian, apa yang menjadi program pemerintah daerah di bidang ekonomi untuk meningkatkan daya beli masyarakat akan mendapatkan dukungan dari Pemerintah Pusat.

3. Kebijakan Subsidi Bantuan Langsung Tunai (BLT) yang dilakukan Pemerintah Pusat

Kebijakan ini ditujukan untuk mengkonvensasi penurunan daya beli masyarakat akibat dampak kenaikan harga bahan bakar minyak (BBM). Dengan adanya kebijakan subsidi bantuan langsung tunai (BLT), masyarakat Kota Bandung khususnya yang berpendapatan rendah akan terbantu dalam meminimalisir penurunan daya beli akibat kenaikan harga minyak (BBM) tersebut. Walaupun tidak selamanya dapat menerima BLT, namun dengan harapan bahwa espektasi terhadap dampak krisis tersebut akan cepat teratasi dengan waktu 


\section{Bayu Kharisma}

tidak terlalu lama maka bantuan tersebut diharapkan akan dapat membantu masyarakat mempertahankan daya beli, terutama dalam jangka pendek.

4. Kebijakan Pemerintah Pusat Mengenai Beras untuk Rakyat Miskin (raskin), Asuransi Kesehatan bagi Rakyat Miskin (askeskin), dan Bantuan Operasional Sekolah (BOS), Program Nasional Pemberdayaan Masyarakat (PNPM), Kredit Usaha Rakyat (KUR) dengan Subsidi Bunga untuk Membantu Masyarakat Berpendapatan Rendah

Kebijakan raksin merupakan subsidi pemerintah pusat bagi rakyat miskin dalam bentuk bahan makanan pokok berupa beras. Dengan raskin, masyarakat miskin dapat mendapatkan beras dengan harga yang ter jangkau karena harganya jauh di bawah harga pasar. Ini berarti daya beli untuk mendapatkan bahan makanan pokok dapat dipertahankan. Bantuan Operasional Sekolah (BOS) merupakan bantuan pemerintah yang dapat dimanfaatkan oleh sekolah sekolah untuk menunjang kegiatan operasional sekolah. Bantuan ini sangat bermanfaat karena sekolah tidak perlu melakukan pungutan - pungutan kepada orang tua siwsa untuk kegiatan operasionalnya. Bagi masyarakat yang pendapatan rendah, bantuan tersebut sangat membantu karena mereka tidak perlu mengeluarkan biaya yang terlalu besar dalam menyekolahkan anaknya. Program Nasional Pemberdayaan Masyarakat Madani (PNPM) merupakan program pemberdayaan masyarakat yang ditujukan untuk membantu dalam mendorong kegiatan ekonomi ril masyarakat. Bantuan melalui program PNPM dapat dimanfaatkan oleh pelaku usaha mikro dan kecil baik individu maupun kelompok dalam bentuk pendanaan usaha. Masyarakat dapat memperoleh bantuan modal dengan persyaratan yang sangat ringan bahkan selain modal merekapun mendapatkan pembinaan dari fasilitator-fasilitator program ini. Dengan model seperti ini peluang keberhasilan menjadi sangat terbuka. Pada akhirnya kenaikkan pendapatan bukan merupakan angan - angan, tetapi akan menjadi kenyataan. Kredit Usaha Rakyat (KUR) dengan subsidi bunga untuk kalangan masyarakat bawah (usaha mikro dan kecil) merupakan program pemerintah pusat untuk membantu mengatasi salah satu kendala yang dihadapi dalam pengembangan usaha mikro dan kecil yaitu permodalan. Usaha mikro dan kecil yang selama ini mengalami kesulitan membayar bunga bank karena mereka dikenakan bunga pasar, dengan KUR mereka akan terbantu karena sebagian dari bunga yang seharusnya mereka bayar disubsidi oleh pemerintah. Ini merupakan peluang bagi usaha mikro dan kecil untuk mengembangkan usaha dan memperbaiki tingkat kesejahteraan mereka.

5. Salah Satu Program yang dilaksanakan Pemerintah Provinsi Jawa Barat pada tahun 2007, yaitu Program Pendanaan Kompetisi akselerasi pencapaian Indeks Pembangunan Manusia (PPK-IPM)

Bergulirnya Program Pendanaan Kompetisi IPM (PPK-IPM) merupakan salah satu bukti komitmen kuat Pemerintah Propinsi Jawa Barat beserta segenap masyarakat mewujudkan pencapaian IPM 80 pada tahun 2010. Program tersebut dapat menjadi lokomotif untuk membangun komitmen bersama di segenap lapisan; Pemerintah Propinsi, Pemerintah Kabupaten/Kota, Swasta dan masyarakat. PPK IPM merupakan bantuan program dari pemerintah propinsi untuk kegiatan usaha di daerah - daerah. Dengan bantuan ini diharapkan kegiatan ekonomi meningkat sehingga daya beli masyarakat juga ikut meningkat. Program ini bersifat terbuka bagi semua daerah di propinsi Jawa Barat. Para pelaku usaha di daerah diharuskan mengajukan proposal pengembangan usaha untuk dinilai kelayakannya untuk mendapatkan bantuan PPK IPM. Dasar penilaian PPK-IPM adalah kegiatan usaha yang diharapkan dapat mengangkat daya beli masyarakat di daerah. Semakin banyak usaha kecil dan menengah di Kota Bandung yang mendapatkan bantuan PPK IPM maka semakin besar peluang peningkatan daya beli masyarakat di wilayah ini. 
6. Adanya UU Otonomi Daerah dapat Memberi Kesempatan dan Keleluasaan Terhadap Pemerintah Daerah Kota Bandung dalam Meningkatkan Kegiatan Perekonomian Kota Bandung Berbasiskan Potensi Derah/Lokal

Peningkatan kegiatan ekonomi berarti membuka peluang terciptanya kesempatan kerja. Dengan adanya penciptaan kesempatan kerja yang bertambah berarti tingkat pengangguran akan berkurang dan kesempatan masyarakat untuk meningkatkan pendapatan sekaligus meningkatkan daya beli akan semakin besar. Dalam pelaksanaan penyelenggaraan otonomi daerah, termasuk desentralisasi fiskal, pemerintah daerah harus memberikan perhatian lebih terhadap revitalisasi dari otonomi daerah. Proses desentralisasi tidak seharusnya lebih memprioritaskan terhadap kebijakan APBD, tetapi secara fakta proses desentralisasi lebih ke arah kesejahteraan penduduk daerah sebagai tujuan utama dalam pembangunan ekonomi daerah. Pengawasan terhadap kinerja pemerintah daerah, baik itu pelaksana (eksekutif) dan legistatif , harus berfokus pada kemampuan pemerintah daerah dalam merevetisasi ekonomi daerah melalui penciptaan lapangan pekerjaan, peningkatan pendapatan perkapita dan pertumbuhan ekonomi yang lebih cepat. Dengan demikian, pelaksanaan otonomi daerah ini merupakan peluang bagi pemerintah daerah untuk mendorong aktivitas ekonomi berbasis kekuatan lokal.

\section{b. Faktor Ancaman (threats)}

1. Dampak Krisis Multimensi (Ekonomi, Sosial dan Politik) yang Terjadi di Dalam Negeri pada Tahun 1997

Krisis perekonomian yang diawali krisis moneter tahun 1997 telah memberikan dampak yang sangat besar terhadap penurunan daya beli masyarakat. Proses recovery dari krisis bagi Indonesia ternyata memakan waktu lebih lama dibanding negara-negara di Asia lainnya. Bahkan sampai sekarang dampak krisis tersebut masih terasa seperti yang ditunjukkan oleh masih tingginya angka kemiskinan dan pengangguran. Kedua indikator tersebut merupakan tantangan bagi Pemerintah Daerah Kota Bandung ke depan untuk dapat menurunkan angka kemiskinan dan pengangguran tersebut. Kemampuan pemerintah daerah menekan angka kemiskinan dan pengangguran sama artinya dengan kempauan pemerintah dalam memperbaiki daya beli masyarakat. Selain itu, dampak sosial dan politik yang terjadi pada tahun 1997 masih menyisakan dampak yang cukup sigifikan dalam mempengaruhi standar kualitas hidup masyarakat. Misalnya, ditandai dengan semakin tingginya tingkat kriminalitas dan yang terjadi di Kota Bandung.

2. Pilkada dan Pilres

Perkembangan ekonomi suatu daerah selain dipengaruhi faktor - faktor ekonomi juga dipengaruhi oleh faktor-faktor non ekonomi, diantaranya faktor sosial dan politik terjadi di tengah-tengah masyarakat. Pada saat ini, setiap daerah dalam pemilihan kepada daerahnya harus ditempuh dengan pemilihan langsung (pilkada langsung). Pilkada langsung merupakan satu proses politik yang telah menjadi realitas di masyarakat. Selain pilkada dalam skala nasional daerah juga akan menghadapi pemilihan umum untuk memilih anggota legislatif dan memilih presiden pada tahun 2009. Dengan adanya pilkada dan pilres ini umumnya secara tidak langsung akan terjadi proses pergantian kepemimpinan yang pda akhirnya akan sangat berpengaruh terhadap kebijakan yang akan ditempuh, terutama kebijakan mengenai peningkatan kualitas standar hidup yang dicerminkan oleh peningkatan daya beli masyarakat. Selanjutnya, hal ini tentunya akan memiliki dampak terhadap pelaksanaan program pemerintah, baik di pusat maupun di daerah.

3. Kenaikan Harga Minyak Dunia

Harga bahan bakar minyak (BBM) di dalam negeri sangat dipengaruhi oleh perkembangan harga minyak mentah dunia. Pada saat ini BBM yang dijual di masyarakat terdiri dari BBM bersubsidi dan BBM non subsidi. Ketika harga minyak 


\section{Bayu Kharisma}

mentah dunia merangkak naik maka pemerintah terpaksa harus melakukan penyesuaian harga minyak domestik untuk mengatasi meningkatnya beban subsidi yang harus dikeluarkan. Dengan demikian, adanya pengurangan subsidi BBM ini secara tidak langsung akan menyebabkan kenaikan terhadap harga BBM yang bersubsidi sehingga pengeluaran untuk membeli BBM juga akan mengalami kenaikan, termasuk untuk barang-barang dan jasa lainnya juga ikut naik. Hal ini secara tidak langsung akan berpengaruh terhadap daya beli

4. Krisis Pangan Dunia

Dengan adanya krisis pangan yang saat ini sedang dialami diberbagai negara di dunia, akan menyebabkan tingginya kenaikan harga beberapa komoditas bahan makanan dan harganya berfluktuasi (volatile food). Permintaan terhadap bahan pangan di dalam negeri sebagian dipenuhi dari luar negeri. Ketika pasokan bahan pangan impor mengalami penurunan makan harga bahan pangan di dalam negeri akan naik. Kenaikan harga bahan pangan menyebabkan untuk memenhuhi kebutuhan pangan masyarakat harus mengeluarkan lebih besar bagian dari pendapatannya. Ini berarti daya beli masyarakat menurun karena dengan anggaran yang sama masyarakat akan memperoleh barang yang sama lebih sedikit.

5. Tingkat Inflasi (Semakin tingginya harga barang dan jasa secara persisten)

Setiap kenaikan tingkat inflasi, daya beli masyarakat akan mengalami penurunan karena masyarakat harus mengeluarkan uang lebih banyak dari pendapatannya untuk mendapatkan barang yang sama. Dalam kondisi perekonomian yang stabil dimana tingkat inflasi relatif cukup rendah, dengan tingkat pendapatan yang sama maka daya beli masyarakat relatif stabil. Sebaliknya daya beli akan berkurang manakala tingkat harga- harga mengalami kenaikan secara persisten (inflasi).

6. Dampak Krisis Kredit Macet untuk perumahan (Subprime Mortgage Crisis) dan Kevangan Global

Krisis kedit macet perumahan di Amerika serika telah menjadi kerisis keuangan di negara tersebut yang dampaknya melanda negara - negara lainnya. Ekspor tekstil dan produk tekstil (TPT) Indonesia sebagian besar ditujukan ke Amerika Serikat pada saat amerika serikat mengalami krisis keuangan ekspor TPT turut terpukul dengan kondisi tersebut. Kota Bandung merupakan salah daerah yang memiliki industri TPT di Jawa Barat sangat merasakan dampak penurunan ekspor. Beberapa perusahaan telah mengalami penurunan produksi akibat pesanan yang menurun tajam. Bahkan beberapa pemilik perusahan telah melakukan langkah lebih jauh untuk menyelamatkan perusahaannya dengan melakukan rasionalisasi karyawan. Langkah ini terpaksa mereka tempuh karena beban biaya operasional sudah tidak lagi sebanding dengan pendapatan yang mereka dari hasil penjualan. Sebagian tenaga kerja di industri TPT terpaksa harus kehilangan pekerjaannya. Dengan demikian, tingkat pengangguran dan kemiskinan pun akan bertambah. Selain itu, dampak krisis keuangan global yang terjadi di Amerika Serikat, secara tidak langsung dapat melemahkan tingkat daya beli masyarakat.

Setelah mengidentifikasikan faktor-faktor yang mempengaruhi kemampuan daya beli masyarakat Kota Bandung. Tahap selanjutnya adalah menghitung bobot berdasarkan hasil penigisian kuesioner oleh responden yang disampaikan pada saat FGD (focus group discussion) dan survey lapangan.

\subsubsection{Matriks EFAS (External Strategic Faktor Analysis Summary)}

Berdasarkan Matriks EFAS (External Strategic Faktor Analysis Summary) menunjukkan bahwa total skor hasil analisis faktor-faktor eksternal yang 
mempengaruhi daya beli masyarakat Kota Bandung sebesar 2,22. Artinya, Pemerintah Daerah Kota Bandung berada pada posisi yang cukup kuat untuk memanfaatkan peluang-peluang yang ada untuk meminimalkan ancaman yang akan timbul yang berkaitan dengan faktor-faktor eksternal yang mempengaruhi daya beli masyarakat Kota Bandung.

Faktor pelvang yang sangat penting dan dapat dimanfaatkan oleh Pemerintah Daerah Kota Bandung dalam upaya peningkatan daya beli masyarakat Kota Bandung adalah Kebijakan Pemerintah Pusat Mengenai Beras untuk Rakyat Miskin (raskin), Asuransi Kesehatan bagi Rakyat Miskin (askeskin), dan Bantuan Operasional Sekolah (BOS), Program Nasional Pemberdayaan Masyarakat (PNPM), Kredit Usaha Rakyat (KUR) dengan Subsidi Bunga untuk Membantu Masyarakat Berpendapatan Rendah yang mencapai skor 0.37 .

Dalam rangka meningkatkan daya beli masyarakat, Pemerintah Pusat sejak awal menyatakan komitmen untuk menurunkan angka kemiskinan menjadi 8,2\% pada tahun 2009. Secara konsisten dalam berbagai kesempatan, komitmen ini diberi penekanan, seperti dalam Nota Keuangan, Pidato Kenegaraan, dan dokumen resmi lainnya. Sebagai implementasi, ada banyak program disertai kucuran dana yang telah dilaksanakan. Ada sekitar 55 program atau proyek yang dilaksanakan oleh sekitar 19 departemen/lembaga pemerintah Non Departemen (LPND) sejak 2004, yang terkait langsung dengan program kemiskinan. Beberapa yang paling populer dan menggunakan dana besar adalah: raskin, askeskin, BOS, P2KP dan PPK. (Pidato Kenegaraan, 2008). Nama program baru dan paling dikedepankan pemerintah untuk penanganan kemiskinan adalah Program Nasional Pemberdayaan Masyarakat (PNPM) Mandiri yang diluncurkan pada tanggal 30 April tahun 2007. Disebutkan bahwa PNPM 2007 mencakup 1.993 kecamatan di perdesaan dan 834 kecamatan di perkotaan atau sekitar 50.000 desa. Tahun 2008, PNPM akan mengintegrasikan seluruh program penanggulangan kemiskinan di berbagai kementerian dan lembaga dan mencakup 3.800 kecamatan. Selanjutnya pada tahun 2009 secara kumulatif seluruh kecamatan di Indonesia (5.263 kecamatan) akan mendapat PNPM ini. Rencananya, Pemerintah pusat akan mengalokasikan dana sampai dengan Rp54 triliun pada tahun 2008. (Nota Kevangan dan Rancangan Anggaran Pendapatan dan Belanja Negara Tahun Anggaran 2009). Dengan demikian, langkah-langkah Pemerintah Pusat dalam mengembangkan kebijakan Beras untuk Rakyat Miskin (raskin), Asuransi Kesehatan bagi Rakyat Miskin (askeskin), dan Bantuan Operasional Sekolah (BOS), Program Nasional Pemberdayaan Masyarakat (PNPM), Kredit Usaha Rakyat (KUR) dengan Subsidi Bunga dapat dioptimalkan oleh Pemerintah Daerah Kota Bandung karena terbukti efektif menghindari merosotnya kemampuan daya beli masyarakat secara luas, termasuk di Kota Bandung. Disamping itu, faktor-faktor eksternal lainnya yang dapat dimanfaatkan oleh Pemerintah Daerah dalam upaya meningkatkan daya beli masyarakat yaitu :

- Adanya UU Otonomi Daerah dapat Memberi Kesempatan dan Keleluasaan Terhadap Pemerintah Daerah Kota Bandung dalam Meningkatkan Kegiatan Perekonomian Kota Bandung Berbasiskan Potensi Derah/Lokal.

- Kebijakan Subsidi Bantuan Langsung Tunai (BLT) yang dilakukan Pemerintah Pusat

- Program yang dilaksanakan Pemerintah Provinsi Jawa Barat pada tahun 2007, yaitu Program Pendanaan Kompetisi akselerasi pencapaian Indeks Pembangunan Manusia (PPK-IPM)

Sementara itu, faktor ancaman terbesar dan harus diminimalisir oleh Pemerintah Daerah Kota Bandung dalam upaya peningkatan daya beli masyarakat Kota Bandung adalah tingkat inflasi (Semakin tingginya harga barang dan jasa secara persisten) yang mencapai skor 0,20. Daya Beli masyarakat Kota Bandung dipengaruhi oleh besarnya tingkat inflasi dari perekonomian, dimana 
semakin besar tingkat inflasi yang terjadi pada perekonomian maka semakin besar juga penurunan daya beli masyarakatnya.

Faktor determinan inflasi di Kota Bandung adalah faktor eksternal dan administered price. Kenaikan harga terutama terjadi pada komoditas yang perkembangan harganya diatur oleh pemerintah (administered price) antara lain peristiwa kenaikan harga minyak bumi di pasar dunia, dari kisaran USD 80/barrel pada tahun 2007 menjadi di atas USD 130/barrel pada pertengahan tahun 2008. Setelah itu, diberlakukan kebijakan Pemerintah Pusat untuk melakukan pengurangan subsidi BBM pada tanggal 24 Mei 2008 dengan mengumumkan kenaikan harga BBM bersubsidi (premium, solar, dan minyak tanah) rata-rata $28,75 \%$. Hal ini secara tidak langsung telah menyebabkan peningkatan beban hidup masyarakat di Kota Bandung, termasuk penurunan daya beli. Hal ini tercermin dari peningkatan porsi pengeluaran rumah tangga yang terjadi pada kelompok makanan, yakni dari 41,43\% menjadi 41,70\% (Bank Indonesia, 2008).

Sementara itu, peningkatan laju inflasi yang didominasi oleh faktor eksternal lainnya yaitu didominasi oleh kenaikan bahan bakar, bahan makanan, emas perhiasan dan makanan jadi. Kenaikan bahan bakar minyak pada akhir Mei 2008 telah menyumbangkan inflasi yang cukup besar dan mendorong kenaikan barang dan jasa lainnya, khususnya pengeluaran masyarakat untuk tarif angkutan yang mencapai di atas 50\% (Laporan Perekonomian Indonesia, 2008). Selain itu kenaikan harga berbagai komoditas strategis internasional (tekanan imported inflation) pada akhirnya menyebabkan kenaikan harga produk akhir yang berbahan baku impor dan kenaikan harga emas perhiasan yang terjadi di Kota Bandung. Berikut ini adalah perkembangan inflasi menurut kota di Propinsi Jawa Barat selama Tahun 2006-2008.

Tabel 4.1. Tingkat Inflasi di Jawa Barat Menurut Kota (\%)

\begin{tabular}{|c|l|c|c|c|c|c|c|c|}
\hline \multirow{2}{*}{ No. } & \multirow{2}{*}{ Kota } & \multirow{2}{*}{ Bobot } & \multirow{2}{*}{$\mathbf{2 0 0 6}$} & \multicolumn{3}{|c|}{$\mathbf{2 0 0 7}$} & \multicolumn{2}{|c|}{$\mathbf{2 0 0 8}$} \\
\cline { 5 - 9 } & & & TW.II & TW.III & TW.IV & TW.I & TW.II \\
\hline 1. & Bandung & $\mathbf{3 9 , 8 2}$ & $\mathbf{1 , 8 7}$ & $\mathbf{- 0 , 2 6}$ & $\mathbf{2 , 4 8}$ & $\mathbf{1 , 8 2}$ & $\mathbf{2 , 8 1}$ & $\mathbf{5 , 8 1}$ \\
\hline 2. & Bekasi & 29,23 & 2,57 & $-0,27$ & 2,65 & 0,81 & 2,31 & 3,98 \\
\hline 3. & Bogor & 15,33 & 2,54 & 0,03 & 1,64 & 0,90 & 3,98 & 2,87 \\
\hline 4. & Sukabumi & 5,40 & 3,04 & $-0,88$ & 1,88 & 3,21 & 2,75 & 3,69 \\
\hline 5. & Cirebon & 4,60 & 4,23 & 0,15 & 2,22 & 2,06 & 3,52 & 4,80 \\
\hline 6. & Tasikmalaya & 3,71 & 3,53 & $-0,04$ & 1,65 & 2,20 & 2,57 & 4,67 \\
\hline 7. & Banjar & 1,92 & 3,31 & 0,17 & 2,66 & 1,95 & 4,69 & 5,02 \\
\hline \multicolumn{2}{l}{ Gabungan } & 100 & 2,40 & $-0,21$ & 2,34 & 1,44 & 3,17 & 4,41 \\
\hline
\end{tabular}

Sumber : BPS Provinsi Jawa Barat

Berdasarkan Tabel 4.1. di atas menunjukkan bahwa inflasi di tujuh kota besar di Propinsi Jawa Barat pada triwulan II Tahun 2008 mengalami peningkatan dibandingkan triwulan sebelumnya, dengan rata-rata di atas $3 \%$. Hanya di Kota Bogor terjadi perlambatan inflasi, dari $3,89 \%$ menjadi $2,87 \%$. Kota dengan inflasi tertinggi adalah Kota Bandung $(5,81 \%)$, sedangkan terendah di Kota Bogor.

Disamping itu, faktor-faktor eksternal lainnya yang menjadi ancaman dan patut diwaspadai oleh Pemerintah Daerah Kota Bandung dalam upaya meningkatkan daya beli masyarakat antara lain adalah :

- Pilkada dan Menjelang Pemilu Presiden 2009

- Krisis Pangan Dunia (imported inflation)

- Dampak Krisis Kredit Macet untuk perumahan (subprime mortgage crisis) dan Krisis Keuangan Global

Tabel 4.2. Matriks EFAS (External Strategic Faktor Analysis Summary)

\begin{tabular}{|l|l|l|l|l|}
\hline \multirow{2}{*}{ No. } & \multirow{2}{*}{ Faktor Strategis Eksternal } & \multicolumn{3}{|c|}{ Bobot x rating } \\
\cline { 3 - 4 } & & Bobot & Rating & Skor \\
\hline
\end{tabular}




\begin{tabular}{|c|c|c|c|c|}
\hline \multicolumn{5}{|c|}{$\begin{array}{l}\text { PELUANG } \\
\end{array}$} \\
\hline 1 & $\begin{array}{l}\text { Kebijakan Pemerintah Pusat Mengenai Konversi } \\
\text { Minyak Tanah ke Liquified Petroleum Gas (LPG) }\end{array}$ & 0.08 & 2.33 & 0.19 \\
\hline 2 & $\begin{array}{l}\text { Muara Pembangunan Nasional adalah } \\
\text { Kesejahteraan Rakyat }\end{array}$ & 0.06 & 3.00 & 0.18 \\
\hline 3 & $\begin{array}{l}\text { Kebijakan Subsidi Bantuan Langsung Tunai (BLT) } \\
\text { yang dilakukan Pemerintah Pusat }\end{array}$ & 0.08 & 2.67 & 0.21 \\
\hline 4 & $\begin{array}{l}\text { Kebijakan Pemerintah Pusat : Beras untuk } \\
\text { Rakyat Miskin (raskin), Asuransi Kesehatan bagi } \\
\text { Rakyat Miskin (askeskin), dan Bantuan } \\
\text { Operasional Sekolah (BOS), Program Nasional } \\
\text { Pemberdayaan Masyarakat (PNPM), Kredit } \\
\text { Usaha Rakyat (KUR) dengan Subsidi Bunga } \\
\text { untuk Membantu Masyarakat Berpendapatan } \\
\text { Rendah }\end{array}$ & 0.10 & 3.67 & 0.37 \\
\hline 5 & $\begin{array}{l}\text { Salah Satu Program yang dilaksanakan } \\
\text { Pemerintah Provinsi Jawa Barat pada tahun } \\
\text { 2007, yaitu Program Pendanaan Kompetisi } \\
\text { akselerasi pencapaian Indeks Pembangunan } \\
\text { Manusia (PPK-IPM) }\end{array}$ & 0.09 & 2.33 & 0.20 \\
\hline 6 & $\begin{array}{l}\text { Adanya UU Otonomi Daerah dapat Memberi } \\
\text { Kesempatan dan Keleluasaan Terhadap } \\
\text { Pemerintah Daerah Kota Bandung dalam } \\
\text { Meningkatkan Kegiatan Perekonomian Kota } \\
\text { Bandung Berbasiskan Potensi Derah/Lokal }\end{array}$ & 0.10 & 2.33 & 0.23 \\
\hline \multicolumn{5}{|c|}{ ANCAMAN } \\
\hline 1 & $\begin{array}{l}\text { Dampak Krisis Multimensi (Ekonomi, Sosial dan } \\
\text { Politik) yang Terjadi di Dalam Negeri Tahun } 1997\end{array}$ & 0.06 & 1.33 & 0.08 \\
\hline 2 & Pilkada dan Pemilu Presiden 2009 & 0.11 & 1.67 & 0.18 \\
\hline 3 & Kenaikan Harga Minyak Dunia & 0.08 & 1.33 & 0.11 \\
\hline 4 & Krisis Pangan Dunia & 0.08 & 2.00 & 0.16 \\
\hline 5 & $\begin{array}{l}\text { Tingkat Inflasi (Semakin tingginya harga barang } \\
\text { dan jasa secara persisten) }\end{array}$ & 0.10 & 2.00 & 0.20 \\
\hline 6 & $\begin{array}{l}\text { Dampak Krisis Kredit Macet untuk perumahan } \\
\text { (Subprime Mortgage Crisis) dan Krisis Keuangan } \\
\text { Global }\end{array}$ & 0.06 & 1.67 & 0.10 \\
\hline & JUMLAH & 1.00 & 26.33 & 2.22 \\
\hline
\end{tabular}

Sumber : Hasil Perhitungan Kuisoner

\subsubsection{Matriks IFAS (Internal Strategic Faktor Analysis Summary)}

Berdasarkan Matriks IFAS (Internal Strategic Faktor Analysis Summary) menunjukkan bahwa total skor hasil analisis faktor-faktor internal yang mempengaruhi daya beli masyarakat Kota Bandung sebesar 2,15. Artinya, Pemerintah Daerah Kota Bandung berada pada posisi yang relatif kuat untuk menggunakan dan memanfaatkan kekuatan-kekuatan yang ada untuk meminimalkan kelemahan-kelemahan yang dihadapi dalam upaya untuk meningkatkan daya beli masyarakat Kota Bandung.

Matriks IFAS memberikan informasi bahwa dari 6 (enam) faktor strategis internal yang merupakan faktor kekuatan Pemerintah Daerah dalam upaya meningkatkan daya beli masyarakat Kota Bandung, menunjukkan bahwa "Komitmen Kuat dari Pemerintah Daerah Kota Bandung untuk Meningkatkan Daya Beli Masyarakat Kota Bandung" memiliki bobot yang paling tinggi yakni 0,30. Hal ini menunjukkan bahwa faktor komitmen yang kuat merupakan faktor yang paling penting bagi Pemerintah Daerah Kota Bandung dibandingkan faktor-faktor internal kekuatan lainnya dalam upaya meningkatkan daya beli masyarakat Kota Bandung. Komitmen merupakan modal dasar untuk membangun suatu kebijakan 


\section{Bayu Kharisma}

yang sungguh-sungguh. Tanpa adanya komitmen yang kuat maka programprogram yang dibuat hanya merupakan aktivitas penggunaan anggaran tanpa peduli hasil yang akan diperoleh.

Bukti tingginya komitmen Pemerintah Kota Bandung dalam meningkatkan daya beli masyarakatnya adalah dengan diluncurkannya Program Bawaku Makmur (Program Bantuan Walikota khusus Bidang Kemakmuran). Untuk itu, sebanyak partisipasi 50.971 usaha mikro, kecil dan menengah (UMKM) sejak akhir 2007, secara bertahap menerima Bantuan Peningkatan Usaha dan Kesejahteraan (Laporan Bantuan Walikota Khusus Bidang Kemakmuran). Program ini dipandang sebagai solusi yang sangat efektif untuk meningkatkan daya beli masyarakat, karena dana hibah yang diberikan oleh pemerintah dapat digunakan untuk menunjang kegiatan ekonomi produktif dengan harapan akan meningkatkan akan meningkatkan pendapatan para penerima bantuan dan memberikan multiplier effect kepada peningkatan daya beli masyarakat Kota Bandung.

Faktor-faktor internal lainnya yang menjadi kekuatan dan dapat dimanfaatkan dan dilakukan oleh Pemerintah Daerah Kota Bandung dalam upaya meningkatkan daya beli masyarakat antara lain adalah :

- Dukungan Secara Politis dari Dewan Perwakilan Rakyat Daerah (DPRD) Kota Bandung terhadap Kebijakan Pemerintah Daerah Kota Bandung Dalam Rangka Peningkatan Daya Beli Masyarakat

- Target Waktu Pencapaian Prioritas Program Sudah Ditetapkan

- Koordinasi Antara SKPD Dalam Pelaksanaan Program Ekonomi Sudah Berjalan dengan Baik

Faktor kelemahan terbesar dan harus diwaspadai dan diminimalisir oleh Pemerintah Daerah Kota Bandung dalam upaya peningkatan daya beli masyarakat Kota Bandung adalah "Lemahnya Kemampuan Monitoring dan Evaluasi Terhadap Program Penguatan Daya Beli" yang mencapai skor 0,26. Monitoring dan evaluasi merupakan fungsi yang sangat penting dalam setiap pelaksanaan program pemerintah kota. Fungsi monitoring adalah memonitor pelaksanaan program yang sedang dilaksanakan supaya tetap tidak terjadi penyimpangan dari rencana. Sementara evaluasi yang dilakukan secara berkala yang bertujuan untuk menilai pekerjaan sedang berjalan dan mengoreksi kesalahan yang terjadi. Berdasarkan survei terhadap program penguatan daya beli, yaitu penerima bantuan program Bawaku, masih banyak peneriman bantuan tersebut ternyata pihak yang tidak berhak menerimannya dan banyak digunakan untuk kegiatan yang bersifat konsumtif bukan untuk modal kerja. Misalnya untuk membeli Handphone dan barang-barang elektronik (Tribun Jawa Barat, 2008).

Berdasarkan hasil evaluasi selama tiga bulan pelaksanaan program Bantuan Wali Kota Khusus (Bawaku) bidang kemakmuran yang diberikan kepada 39.918 orang dengan nilai Rp 25,4 miliar ternyata tidak signifikan. Bantuan itu hanya meningkatkan daya beli di bawah 1 persen. Para penerima Bawaku Makmur mulai dari Rp 500 ribu sampai Rp 5 juta, penghasilan mereka tidak bertambah karena daya beli tidak meningkat. Selain itu, program Bawaku yang sudah cair dari 39.918 proposal yang tepat sasaran digunakan kebutuhan produktif 88 persen, sedangkan sisanya digunakan konsumtif (Lusi Lesminingwati, Tribun Jawa Barat, 2008). Masih adanya penggunaan dana Bawaku yang tidak tepat sasaran antara lain disebabkan karena masih lemahnya kemampuan monitoring dan evaluasi program tersebut dari Pemerintah Daerah Kota Bandung.

Tabel 4.3. Matriks IFAS (Internal Strategic Faktor Analysis Summary)

\begin{tabular}{|c|c|c|c|c|}
\hline \multirow{2}{*}{ No. } & \multicolumn{3}{|c|}{ Bobot $x$ rating } \\
\cline { 3 - 4 } & Baktor Strategis Internal & Rating & Skor \\
\hline \multicolumn{2}{|c|}{ KEKUATAN } \\
\hline
\end{tabular}




\begin{tabular}{|c|c|c|c|c|}
\hline 1 & $\begin{array}{l}\text { Komitmen Kuat dari Pemerintah Daerah Kota } \\
\text { Bandung untuk Meningkatkan Daya Beli } \\
\text { Masyarakat Kota Bandung }\end{array}$ & 0.10 & 3.00 & 0.30 \\
\hline 2 & $\begin{array}{lll}\text { Program-Program Pemerintah Daerah } & \text { Kota } \\
\text { Bandung Sudah Mencakup Semua Sektor } & \end{array}$ & 0.07 & 1.33 & 0.10 \\
\hline 3 & Target dan Sasaran Sudah Sangat Jelas & 0.07 & 2.33 & 0.16 \\
\hline 4 & $\begin{array}{l}\text { Dukungan Secara Politis dari Dewan Perwakilan } \\
\text { Rakyat Daerah (DPRD) Kota Bandung terhadap } \\
\text { Kebijakan Pemerintah Daerah Dalam Rangka } \\
\text { Peningkatan Daya Beli Masyarakat }\end{array}$ & 0.09 & 3.00 & 0.27 \\
\hline 5 & $\begin{array}{l}\text { Target Waktu Pencapaian Prioritas Program } \\
\text { Sudah Ditetapkan }\end{array}$ & 0.09 & 2.00 & 0.18 \\
\hline 6 & $\begin{array}{l}\text { Koordinasi Antara SKPD Dalam Pelaksanaan } \\
\text { Program Ekonomi Sudah Berjalan dengan Baik }\end{array}$ & 0.07 & 2.67 & 0.20 \\
\hline \multicolumn{5}{|c|}{ KELEMAHAN } \\
\hline 1 & $\begin{array}{l}\text { Sosialisasi Program-Program Kepada Masyarakat } \\
\text { yang Berkaitan dengan Penguatan Daya Beli } \\
\text { dirasakan Masih Lemah }\end{array}$ & 0.08 & 2.33 & 0.19 \\
\hline 2 & $\begin{array}{l}\text { Standar Pelayanan Minimum (SPM) Belum } \\
\text { Sepenuhnya Terlaksana dengan Baik }\end{array}$ & 0.07 & 2.33 & 0.16 \\
\hline 3 & $\begin{array}{l}\text { Kemampuan Alokasi Anggaran Pemerintah } \\
\text { Daerah Kota Bandung yang Berkaitan Dengan } \\
\text { Program Peningkatan Daya Beli Masih Rendah }\end{array}$ & 0.11 & 1.00 & 0.11 \\
\hline 4 & $\begin{array}{l}\text { Ketersediaan dan Kemampuan Sumber Daya } \\
\text { Manusia (aparatur) yang Berkaitan langsung } \\
\text { dengan Program Daya Beli Masih Terbatas }\end{array}$ & 0.08 & 2.00 & 0.16 \\
\hline 5 & $\begin{array}{l}\text { Lemahnya Kemampuan Monitoring dan Evaluasi } \\
\text { Program Penguatan Daya Beli }\end{array}$ & 0.13 & 2.00 & 0.26 \\
\hline 6 & Ketersediaan Sistem Informasi dan Data Base & 0.04 & 2.00 & 0.08 \\
\hline \multicolumn{2}{|r|}{ JUMLAH } & 1.00 & 25.00 & 2.15 \\
\hline
\end{tabular}

Sumber : Hasil Perhitungan Kuisoner

\subsection{Analisis AHP (analytical hierarky process) untuk Mengevaluasi Kebijakan Ekonomi Dalam Upaya Meningkatkan Daya Beli Masyarakat Kota Bandung}

Penyusunan hirarki kebijakan ekonomi dalam upaya meningkatkan daya beli masyarakat diturunkan dari kebijakan ekonomi Kota Bandung yaitu yaitu "mengupayakan peningkatan kegiatan perekonomian kota yang berbasiskan daerah" yang dituangkan dalam berbagai program (Perda No. 6 Tahun 2004). Berdasarkan pembagian jenis hirarki yang ada, maka hirarki dalam kajian ini merupakan hirarki tak sempurna, dimana tidak setiap elemen pada suatu level berhubungan dengan elemen yang di atasnya.

\subsubsection{Identifikasi Setiap Level}

1. Level 1 : Tujuan

Fokus hirarki secara umum adalah evaluasi kebijakan ekonomi dalam meningkatkan daya beli masyarakat Kota Bandung yang dituangkan dalam program-program. Perumusan fokus tersebut didasarkan pada tingginya tingkat capaian keberhasilan pembangunan Kota Bandung (yang tercemin dari angka IPM) selama tahun 2003 sampai dengan 2007, ternyata tidak ditandai oleh peningkatan yang berarti pada salah satu komponen IPM, yaitu indeks daya beli (IDB) yang masih menunjukkan perkembangan lambat. Selain itu, apabila diperhatikan dari kehidupan masyarakat yang sebenarnya, justru mengalami kesulitan/keterpurukan serta masih banyaknya terdapat kepala kelvarga yang tergolong miskin. Oleh karena itu, dengan adanya evaluasi terhadap kebijakan ekonomi daya beli masyarakat Kota Bandung diharapkan 


\section{Bayu Kharisma}

Pemerintah Daerah Kota Bandung dapat meningkatkan daya beli masyarakatnya melalui program-program yang telah dilakukan saat ini.

\section{Level 2 : Kondisi Eksisting}

Tujuan dari level ini adalah untuk melihat sumber potensi dan permasalahan yang mempengaruhi daya beli masyarakat Kota Bandung. Terdapat 2 (dua) kondisi eksisiting yang harus dipertimbangkan berdasarkan urutan prioritasnya. Pertama, faktor internal ke dua adalah faktor eksternal.

\section{Level 3 : Aktor}

Tujuan dari level ini adalah untuk melihat aktor-aktor yang berperan penting dalam mempengaruhi kondisi daya beli di Kota Bandung. Aktor-aktor dalam hal ini adalah : Instansi Daerah (perangkat daerah yang terkait), Masyarakat, Pelaku Usaha.

\section{Level 2 : Kebijakan}

Tujuan level ini adalah melihat perbandingan prioritas program-program yang merupakan derivasi dari kebijakan ekonomi yang saat ini atau sedang dilaksanakan dalam rangka peningkatan terhadap daya beli masyarakat Kota Bandung. Penetapan alternatif-alternatif program ini didasarkan pada kebijakan ekonomi Kota Bandung yaitu "mengupayakan peningkatan kegiatan perekonomian kota yang berbasiskan potensi daerah". Selanjutnya kebijakan ini dituangkan dalam berbagai bentuk program-program, antara lain adalah :

- Program Pembinaan dan Pengembangan Usaha Industri

- Program Pembinaan dan Pengembangan Usaha Perdagangan

- Program Pembinaan dan Pengembangan Usaha Koperasi

- Program Pembinaan Usaha Kecil

- Program Peningkatan Investasi Kota

- Program Pembinaan Pemasaran Parawisata

- Program Pengembangan Produk Keparawisataan

- Program Pengembangan Agribisnis

\subsubsection{Estimasi Model}

Untuk keperluan analisis evaluasi kebijakan, responden yang dipilih berjumlah 15 (lima belas) orang atau responden yang berperan penting dalam Evaluasi Program - Program Strategis Pemerintah Kota Bandung di Bidang Ekonomi dalam upaya penguatan dan peningkatan kemampuan daya beli masyarakat kebijakan ekonomi meningkatkan daya beli masyarakat Kota Bandung, antara lain yaitu kelompok masyarakat dan pelaku usaha yang pada dasarnya mampu memberikan kontribusi terhadap evaluasi kebijakan ekonomi meningkatkan daya beli masyarakat Kota Bandung, perangkat daerah atau instansi pemerintah sebagai policy maker terhadap program-program yang berkaitan dengan peningkatan daya beli masyarakat. Hasil penilaian atau perbandingan responden terhadap elemen suatu hirarki diolah dengan menggunakan program super Decision 1.60, sehingga diperoleh bobot prioritas dan sintesa akhir (lokal dan global), serta total/gabungan persepsi responden dengan menggunakan rata-rata ukur (geometric mean). 

Tingkat I

Tujuan

Tingkat II Kriteria

Tingkat IV Alternatif

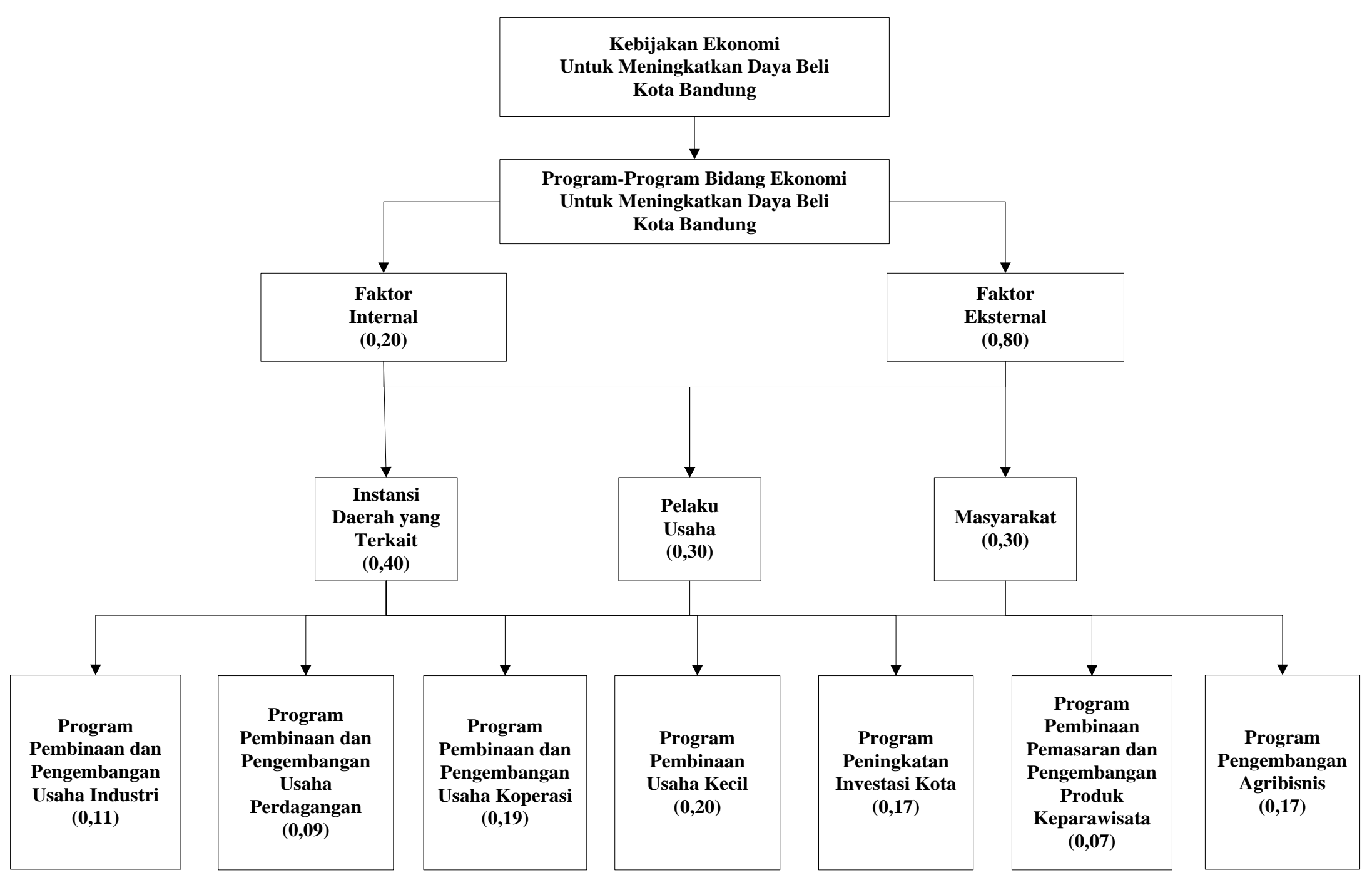

Gambar 4.1.

Hirarki Evaluasi Program - Program Strategis Pemerintah Kota Bandung di Bidang Ekonomi dalam Upaya Penguatan dan Peningkatan Kemampuan Daya Beli Masyarakat Kota Bandung 


\subsection{Analisis Preferensi Masyarakat, Pelaku Usaha dan Instansi Pemerintah}

Berdasarkan hasil estimasi pada Gambar 4.1. terhadap analisis preferensi instansi daerah terhadap evaluasi kebijakan daya beli masyarakat Kota Bandung menunjukkan bahwa faktor eksternal (nilai bobot 0,80) merupakan aspek paling prioritas yang perlu diperhatikan dalam evaluasi kebijakan ekonomi dalam meningkatkan daya beli masyarakat di Kota Bandung. Faktor berikutnya adalah faktor internal (nilai bobot 0,20). Hal ini menunjukkan bahwa faktor-faktor yang tidak dapat dikendalikan (uncontrollable) oleh Pemerintah Daerah Kota Bandung lebih dominan dan berpengaruh besar dibandingkan faktor-faktor yang dapat dikendalikan lasngsung oleh pemerintah Daerah Kota Bandung dalam mempengaruhi kondisi daya beli Masyarakat Kota Bandung. Faktor eksternal tersebut antara lain adalah : tingkat inflasi, Pilkada dan Menjelang Pemilu Presiden, Krisis Pangan Dunia (imported inflation) dan Dampak Krisis Kredit Macet untuk perumahan (subprime mortgage crisis) dan Krisis Keuangan Global.

Untuk mengantisipasi faktor eksternal tersebut, ada beberapa hal yang dapat dilakukan oleh Pemerintah Daerah Kota Bandung, antara lain : meningkatkan laju pertumbuhan ekonomi (LPE) daerah, mengendalikan laju inflasi dan menurunkan tingkat pengangguran. Peningkatan laju pertumbuhan ekonomi bukan hanya digerakkan oleh sektor riil, melainkan dapat dilihat dari faktor konsumsi masyarakat. Hal ini mengindikasikan bahwa tingkat kemakmuran masyarakat dapat terjamin sering dengan meningkatnya laju pertumbuhan ekonomi daerah (LPE) dan akhirnya berkorelasi positif dengan meningkatnya daya beli masyarakat. Namun peningkatan LPE ini diharapkan dibarengi dengan disparitas pendapatan yang rendah. Untuk lebih jelasnya dapat dilihat pada Tabel 4.4. di bawah ini.

Tabel 4.4. Hubungan Indikator Makroekonomi dengan Standar Hidup Layak Konsumsi Per Kapita yang Disesuaikan Tahun 2003-2007

\begin{tabular}{|c|c|c|c|c|c|c|c|}
\hline \multirow[b]{2}{*}{ No. } & \multirow{2}{*}{ Keterangan } & \multirow{2}{*}{ Satuan } & \multicolumn{5}{|c|}{ Tahun } \\
\hline & & & 2003 & 2004 & 2005 & 2006 & 2007 \\
\hline 1. & LPE (Konstan) & $\%$ & 7,34 & 7,49 & 7,53 & 7,83 & 8,24 \\
\hline 2. & $\begin{array}{l}\text { Jumlah } \\
\text { Pengangguran }\end{array}$ & jiwa & 211,21 & 121,59 & 175,34 & 175,64 & 174,07 \\
\hline 3. & Inflasi & $\%$ & 5,69 & 7,56 & 19,56 & 5.33 & 5,21 \\
\hline 4. & $\begin{array}{l}\text { Standar hidup } \\
\text { Layak Konsumsi } \\
\text { per Kapita } \\
\text { yang } \\
\text { disesuaikan }\end{array}$ & $\begin{array}{l}\text { (ribu } \\
\text { Rp) }\end{array}$ & 572,41 & 574,12 & 576,62 & 576,89 & 577,13 \\
\hline
\end{tabular}

Sumber : BPS Kota Bandung

Pada Tabel 4.4. di atas menunjukkan bahwa apabila Pemerintah Daerah dapat mencapai dan mempertahankan tingkat laju pertumbuhan ekonomi (LPE) yang tinggi maka standar hidup layak konsumsi perkapita yang disesuaikan akan mengalami kenaikan. Artinya, dengan semakin tinggi tingkat laju pertumbuhan ekonomi maka daya beli masyarakat akan semakin tinggi. Sementara itu, disisi lain tingkat pengangguran dan inflasi mengalami penurunan. Sementara itu, berdasarkan analisis preferensi pelaku usaha, masyarakat dan instansi pemerintah terhadap aktor-aktor yang berperan penting dalam penguatan daya beli masyarakat Kota Bandung menunjukkan bahwa instansi pemerintah daerah yang terkait sangat berperan penting dalam mempengaruhi kondisi daya beli masyarakat Kota Bandung melalui kebijakan-kebijakan dan program-program yang telah ditempuhnya dengan skor 0,4. Namun keberhasilan kebijakan yang dilakukan Pemerintah Daerah Kota Bandung tidak terlepas dari partisipasi masyarakat dan stakeholder yang terlibat didalamnya.

Berdasarkan perbandingan prioritas alternatif-alternatif kebijakan yang dituangkan dalam bentuk program-program berdasarkan persepsi gabungan 


\section{Bayu Kharisma}

(masyarakat, pelaku usaha, masyarakat dan instansi pemerintah) menunjukkan bahwa Program pengembangan dan pembinaan usaha kecil merupakan program yang paling prioritas dan perlu diperhatikan Pemerintah Daerah Kota Bandung dalam meningkatkan daya beli masyarakat di Kota Bandung dengan total skor mencapai 0,20. Secara implisit bahwa preferensi para responden dari sisi faktor internal lebih memprioritaskan program pembinaan usaha kecil dibandingkan program lainnya dalam upaya meningkatkan daya beli masyarakat Kota Bandung. Hal ini menunjukkan bahwa sudah saatnya pemerintah harus mempunyai komitmen yang kuat dalam mengembangkan usaha kecil, program yang lebih terarah, target dan sasaran program lebih jelas, koordinasi yang baik antar Satuan Kerja Perangkat Daerah (SKPD), sosialisasi program yang terarah, kemampuan anggaran yang reasonable dan monitoring dan evaluasi yang berkala terus dilakukan.

Sementara itu, terpilihnya program pembinaan usaha kecil merupakan program yang lebih prioritas dibandingkan program lainnya dari sisi eksternal menunjukkan bahwa pengembangan usaha kecil mampu bertahan dalam menghadapi faktor-faktor eksternal. Usaha kecil tergolong jenis usaha marginal yang ditandai dengan penggunaan teknologi yang relatif sederhana, tingkat modal dan akses terhadap kredit yang rendah, serta cenderung berorientasi pada pasar lokal.

Preferensi para responden untuk mengutamakan program pembinaan usaha kecil dalam meningkatkan daya beli masyarakat di Kota Bandung adalah hal yang logis mengingat ada beberapa hal yang melandasi pentingnya pembinaan usaha kecil dalam upaya meningkatkan daya beli masyarakat di Kota Bandung, antara lain adalah sebagai berikut:

1. Memprioritaskan program pembinaan usaha kecil

Memprioritaskan program pembinaan usaha kecil diharapkan dapat menciptakan lapangan kerja melalui peningkatan investasi yang sesuai dengan daya dukung lingkungan dan potensi lokal. Disamping itu, pembinaan usaha kecil juga merupakan salah satu komponen utama yang berpotensi meningkatkan posisi tawar (bargaining position) mayarakat.

2. Dengan membangun sinergitas pemberdayaan koperasi dan usaha mikro kecil menengah (KUMKM) berdasarkan potensi lokal dan kewilayahan

Dengan membangun sinergitas pemberdayaan koperasi dan usaha mikro kecil menengah (KUMKM) berdasarkan potensi lokal dan kewilayahan diharapkan dapat meningkatkan penyerapan tenaga kerja yang berdampak terhadap peningkatan daya beli masyarakat.

3. Industri kecil mampu menyerap banyak tenaga kerja. Kecenderungan menyerap banyak tenaga kerja umumnya membuat banyak industri kecil juga intensif dalam menggunakan sumberdaya alam lokal.

Pertumbuhan Industri kecil akan menimbulkan dampak positif terhadap peningkatan jumlah tenaga kerja, pengurangan jumlah kemiskinan, pemerataan dalam distribusi pendapatan, dan pembangunan ekonomi di daerah (Simatupang, et al., 1994; Kuncoro, 1996).

4. Usaha kecil tidak hanya memberikan penghasilan bagi sebagian besar angkatan kerja di Kota Bandung, namun juga merupakan ujung tombak dalam upaya pengentasan kemiskinan

Peran penting usaha kecil dapat memberikan tambahan pendapatan (Sandee et al., 1994), merupakan seedbed bagi pengembangan industri dan sebagai pelengkap produksi pertanian bagi penduduk miskin (Weijland, 1999). Dengan demikian, dapat dikatakan bahwa usaha kecil juga berfungsi sebagai strategi mempertahankan hidup (survival strategy) di tengah krisis ekonomi.

5. Usaha kecil juga mampu bertahan menghadapi goncangan krisis ekonomi yang melanda Indonesia sejak pertengahan tahun 1997

Indikatornya antara lain, serapan tenaga kerja antara kurun waktu sebelum krisis dan ketika krisis berlangsung tidak banyak berubah, dan pengaruh negatif krisis terhadap pertumbuhan jumlah usaha kecil lebih rendah dibanding 
pengaruhnya pada usaha menengah dan besar. Lebih jauh lagi, usaha kecil telah berperan sebagai penyangga (buffer) dan katup pengaman (safety valve) dalam upaya mendorong pertumbuhan ekonomi, serta menyediakan alternatif lapangan pekerjaan bagi para pekerja sektor formal yang terkena dampak krisis.

Meskipun demikian, ada beberapa permasalahan yang sering dihadapi oleh pengusaha kecil, antara lain : Pertama, kelemahan dalam memperoleh peluang pasar dan memperbesar pangsa pasar. Kedua, kelemahan dalam struktur permodalan dan keterbatasan untuk memperoleh jalur terhadap sumber-sumber permodalan. Ketiga, kelemahan di bidang organisasi dan manajemen sumber daya manusia. Keempat, keterbatasan jaringan usaha kerjasama antar pengusaha kecil (sistem informasi pemasaran). Kelima, iklim usaha yang kurang kondusif, karena persaingan yang saling mematikan. Keenam, pembinaan yang telah dilakukan masih kurang terpadu dan kurangnya kepercayaan serta kepedulian masyarakat terhadap usaha kecil. Ketujuh, persaingan semakin ketat disebabkan oleh masuknya produk-produk luar negeri, khususnya Cina dan Korea.

Selanjutnya, urutan prioritas program-program lainnya yang dapat diperhatikan dan dipertimbangkan oleh Pemerintah Daerah dalam upaya peningkatan daya beli Masyarakat Kota Bandung adalah : Program pembinaan dan pengembangan Usaha Koperasi (nilai bobot 0,19), Program peningkatan investasi kota dan Program pengembangan agribisnis (nilai bobot 0,17 ). Program pembinaan dan pengembangan usaha industri (nilai bobot 0,11 ), Program pembinaan dan pengembangan usaha perdagangan (nilai bobot 0,09), Program pembinaan pemasaran parawisata dan Program produk keparawisataan (nilai bobot 0,07$)$. Sementara itu, beberapa evaluasi terhadap program-program lainnya yang bukan prioritas utama dalam meningkatkan daya beli masyarakat Kota Bandung adalah sebagai berikut.

\section{Program pembinaan dan pengembangan Usaha Industri}

- Pengembangan industri kecil, khususnya yang berorientasi ekspor baik industri manufaktur maupun agro industri

Usaha industri harus diarahkan pada ekspor supaya dapat meningkatkan nilai jual produk industri Kota Bandung dan menambah penerimaan devisa negara. Jika nilai jual produk industri tinggi maka pendapatan usaha industri meningkat sehingga kemampuan memberikan upah kepada tenaga kerja juga tinggi.

- Pembinaan usaha industri dalam peningkatan teknik produksi untuk meningkatkan produktivitas

Upaya pembinaan ini dapat dilakukan dengan program - program pelatihan bagi pelaku - pelaku usaha industri. Semakin tinggi skil yang dimiliki pelaku usaha industri maka akan semakin tinggi pula produktivitasnya. Peningkatan produktivitas akan diikuti oleh peningkatan pendapatan.

- Pembinaan standardisasi produk industri terutama yang berorietasi ekspor supaya memiliki daya saing dan diterima oleh pasar luar negeri.

Standardisasi produk perlu dilakukan selain merupakan tuntutan pasar global juga untuk mencegah terambilnya pangsa pasar produk industri lokal oleh produk - produk impor. Jika produk hasil industri Kota Bandung telah memiliki standar internasional maka pangsa pasarnya akan bertambah luas, baik di dalam negeri maupun di luar negeri.

- Menumbuhkan industri yang berwawsan lingkungan dengan meningkatkan dan mengembangakan komoditi yang menjadi andalan/unggulan Kota Bandung

Tuntutan pasar global terhadap produk industri selain harus terstandardisasi juga harus berwawasan lingkungan. Negara - negara maju yang 
merupakan pasar potensial barang - barang hasil industri dari negara negara berkembang termasuk Indonesia sangat gencar mengkampanyekan produk -produk berwawasan lingkungan. Jika produk hasil industri Kota Bandung mampu memenuhi tuntutan kualitas dan lingkungan maka pasar tertutama pasar luar negeri akan mudah menerimanya.

\section{Program Pembinaan dan pengembangan Usaha Perdagangan}

- Membuka akses keuangan yang berfungsi memfasilitasi, memberikan informasi, dan meningkatkan kemampuan usaha sesuai potensi dan karakter lokal.

Kondisi UKM saat ini ditandai dengan rendahnya motivasi usaha dan keterampilan, lemahnya pengelolaan usaha, serta keterbatasan modal, teknologi dan informasi.

- Pemberdayaan SDM pelaku usaha perdagangan melalui bimbingan teknis perdagangan dalam dan luar negeri

Melalui kerja sama dengan Departemen Perdagangan dapat dilakukan pemberian bimbingan teknis perdagangan baik perdagangan domestik maupun perdagangan luar negeri (ekspor - impor) bagi pelaku usaha terutama yang rerorientasi ekspor di Kota Bandung.

- Pengembangan usaha dan kelembagaan melalui kegiatan Lokakarya / Temu Usaha

Berbagai cara atau kiat sukses mengembangkan usaha dapat dilakukan melalui kegiatan lokakarya /temu usaha. Pengusaha - pengusaha sukses dapat berbagi pengalaman di forum ini. Kegiatan ini juga dapat dimanfaatkan untuk menjalin relasi bisnis.

- Bantuan Promosi melalui kegiatan pameran dagang dan penerbitan brosur / leaflet

Kendala usaha kecil selain permodalan adalah pemasaran produk. Bantuan promosi melalui kegiatan pameran diharapkan dapat membantu mengatasi kendala tersebut. Dengan promosi produk usaha kecil akan dikenal oleh konsumen dengan segmen lebih luas. Ini menjadi pelung bagi usaha kecil untuk memperluas pasar produknya.

- Bantuan Pemasaran melalui kegiatan misi dagang ke regional, nasional dan internasional

Sama halnya seperti bantuan promosi bantuan pemasaran ke tingkat regional, nasional dan internasional akan membantu memperluas pasar produk industri Kota Bandung. Pasar yang semakin luas akan memacu pelaku - pelaku usaha perdagangan di Kota Bandung meningkatkan produktivitasnya.

- Perlindungan Konsumen melalui kegiatan Tera Ulang dan pengawasan barang dan jasa beredar

Perlindungan konsumen merupakan suatu tindakan yang tidak dapat diabaikan di era keterbukaan ini. Penjual tidak lagi dapat membohongi konsumen dengan produk-produk yang mereka jual. Kini merupakan era dimana konsumen dapat menentukan eksistensi usaha yang dijalankan seorang pengusaha di suatu pasar. Jika konsumen merasa terlindungi hak haknya maka akan muncul loyalitas dan kepercayaan mereka pada pelaku usaha perdagangan lokal.

- Penyelenggaraan Pasar Murah untuk sembako dalam rangka kegiatan operasi pasar

Operasi Pasar sembako biasanya ditujukan untuk membantu masyarakat berpendapan rendah memperoleh sembako dengan harga murah. Pada saat daya beli masyarakat tergerus akibat kenaikan harga BBM. Dengan demikian, operasi pasar sembako sangat membantu mereka mempertahankan daya beli. 


\section{Program Pembinaan dan Pengembangan Usaha Koperasi}

- Program Peningkatan Pelayanan Koperasi

Program ini diharapkan akan mampu menarik minat masyarakat menjadi anggota koperasi. Selama ini masyarakat merasakan koperasi tidak dapat memberikan pelayanan lebih baik daripada perusahaan non koperasi. Koperasi sebenarnya mampu melakukan pelayanan sama bahkan lebih baik dari pada perusahaan non koperasi jika partisipasi masyarakat (khususnya anggota) di koperasi juga tinggi.

- Program Peningkatan Kapasitas Sumber Daya Manusia

Kapasitas Sumber daya manusia pengelola koperasi di Kota Bandung perlu ditingkatkan mengingat persaingan antar organisasi usaha pada saat ini tidak dapat dihindari lagi. Kopersi tidak lari dari persaingan dengan perusahaan non koperasi jika usahanya ingin tumbuh dan berkembang. Prasyarat untuk dapat berkembang, salah satunya adalah kualitas dan profesionalisme pengelola koperasi.

- Program Peningkatan dan Pengembangan Sistem Pelaporan Kinerja dan Kevangan

Sistem pelaporan kinerja dan keuangan merupakan tuntuan suatu organisasi usaha di era trasparansi saat ini. Kinerja yang bagus dan pelaporan keuangan yang transparan akan meningkatkan kepercayaan masyarakat kepada koperasi.

- Program Peningkatan Promosi dan Kerjasama Investasi

Kopesi seperti perusahaan non koperasi perlu melakukan kegiatan promosid untuk meningkatkan citranya di mata masyarakat. Selain itu koperasi perlu menjalin kerjasama investasi untuk meningkatkan nilai asset yang dimiliki koperasi.

- Program Pengembangan Sistem Pendukung Usaha bagi Usaha Mikro Kecil Menengah

Program ini ditujukan untuk merevitalisasi koperasi sebagai pendukung bagi usaha mikro, kecil dan menengah. Koperasi dapat memberikan manfaat bagi usaha mikro, kecil dan menengah dari segi bantuan modal, pengadaan bahan baku dan pemasaran produk. Koperasi diharapkan dapat mengurangi ketidakpastian usaha bagi ketiga jenis pelaku usaha tersebut.

- Program Peningkatan Kualitas Kelembagaan Koperasi

Kualitas kelembagaan koperasi perlu diperkokoh supaya memilki daya saing di pasar dan mampu menjadi soko guru perekonomian masyarakat. Koperasi harus selalu dijalankan dengan visi ekonomi dan pelayanan kepada anggota.

\section{Program Peningkatan Investasi Kota}

- Merealisasikan kawasan terpadu Gedebage dan menata kembali kawasan - kawasan ekonomi yang sudah ada sehingga mampu meningkatkan nilai ekonomis kawasan tersebut sekaligus menjadi pusat - pusat pertumbuhan.

- Pengembangan sistem dan jaringan transportasi (terutama untuk angkutan manusia) melalui berbagai moda untuk mengurangi kemacetan dan meningkatkan kelancaran distribusi sumber daya.

5. Program Pengembangan Pemasaran Pariwisata dan Pengembangan Produk Keparawisataan

- Mengkomunikasikan dan memasarkan produk baru melalui proses kognisi; mulai dari pengenalan produk, kesadaran akan merek (brand awareness), lalu citra merek (brand image), hingga loyalitas pada merek (brand loyalty).

- Meningkatkan kualitas pelayananan di tempat - tempat wisata

Sektor pariwisata dapat menjadi andalan sumber pendapatan daerah jika pengelolaan objek - objek wisatanya dikelola dengan baik dan profesional. Salah satu ciri profesionalisme pengelolaan tempat wisata adalah 
memberikan kualitas pelayanan bagi wisatawan yang datang. Kualitas pelayanan akan berpengaruh signifikan terhadap tingkat kunjungan wisatawan ke objek-objek wisata. Semakin banyak wisatawan berkunjung ke suatu objek wisata, semakin terbuka kesempatan membuka usaha dan semakin luas pula kesempatan kerja.

\section{Pengembangan Agrobisnis}

- Peningkatan pembiayaan dengan memperbanyak alternatif sumber pembiayaan

Upaya ini diharapkan dapat mengurangi ketergantungan pembiayaan dari pemerintahah dan mendorong kemandirian pelaku usaha.

- Kerjasama perdagangan agro dengan negara lain

Kota Bandung sebagai ibukota Propinsi dapat menjadi pusat perdagangan produk agro di Jawa Barat. Dengan posisi ini Kota Bandung dapat memfasilitasi perdagangan agro antar negara.

- Kerjasama perdagangan agro dengan daerah lain atau antar pulau Dalam skala nasional Kota Bandung berpotensi menjadi pusat perdagangan agro antar daerah di Propinsi Jawa Barat dan antar Pulau di Indonesia.

- Pengembangan sistem logistik produk agro untuk meningkatkan posisi tawar produk agro Kota Bandung.

Kota Bandung dengan infrastruktur ekonomi yang lebih baik dibandingkan daerah - daerah lain di Jawa Barat diharapkan mampu mengembangkan sistem logistik produk agro. Kota Bandung memiliki terminal peti kemas di Gede Bage, akses jalan menuju pelabuhan Tanjung Priok Jakarta dan Pelabungan Cirebon. Dengan infrastruktur ini arus barang dari Kota Bandung ke daerah - daerah lain bahkan luar negeri akan berjalan lancar.

- Pengembangan pasilitasi distribusi produk agro

Kota Bandung dengan infrastruktur lebih bagus dibanding daerah - daerah lain di Jawa Barat sangat memungkinkan untuk dapat memfasilitasi distribusi produk agro antar daerah.

Ada beberapa rekomendasi kebijakan yang diharapkan dapat meningkatkan daya beli masyarakat Kota Bandung, yaitu :

- Mengembangkan usaha kecil untuk memberikan kontribusi yang signifikan terhadap pertumbuhan ekonomi, penciptaan lapangan kerja, peningkatan daya saing dan peningkatan kesejahteraan masyarakat, khususnya yang berpendapatan rendah.

- Program penguatan ekonomi lokal disalurkan dalam bentuk dana kepada usaha produktif yang bertujuan untuk membantu kebutuhan permodalan usaha mikro dan kecil dengan mekanisme yang baik dan tepat sasaran dengan pengawasan dan evaluasi secara berkala. Selama ini salah satu bentuk dana dari program Bantuan Wali Kota Khusus (Bawaku) bidang kemakmuran yang diberikan kepada 39.918 orang dengan nilai Rp 25,4 miliar ternyata tidak signifikan. Bantuan itu hanya meningkatkan daya beli di bawah 1 persen. Para penerima Bawaku Makmur mulai dari Rp 500 ribu sampai Rp 5 juta, penghasilan mereka tidak bertambah karena daya beli tidak meningkat. Selain itu, program Bawaku yang sudah cair dari 39.918 proposal yang tepat sasaran digunakan kebutuhan produktif 88 persen, sedangkan sisanya digunakan konsumtif. Selain itu, dalam rangka mengurangi kemiskinan dan meningkatkan daya beli masyarakat, Pemerintah Daerah Kota Bandung dapat memanfaatkan program PPK-IPM yang bersumber dari APBD Pemprov Jabar dan dana pendamping yang dialokasikan dari APBD Kota Bandung dengan mekanisme yang tepat dan terarah, khususnya alokasi dana bagi usaha produktif yang bertujuan untuk membantu kebutuhan permodalan usaha mikro dan kecil. 
- Mendorong laju investasi, baik pemerintah maupun swasta kepada pembangunan yang mengarah ke daerah-daerah kecamatan yang kurang berkembang yang berada di Kota Bandung. Selain itu, dalam rangka meningkatkan kemampuan daya beli masyarakat di Kota Bandung, upaya pengembangan usaha skala mikro dapat menjadi alternatif pilihan untuk mendongkrak pendapatan masyarakat yang relatif tertinggal.

- Memperkuat kelembagaan dengan jalan: memperluas akses kepada sumber permodalan khususnya perbankan; memperbaiki lingkungan usaha dan menyederhanakan prosedur perijinan; meningkatkan kualitas institusi pendukung, intermediasi sebagai penyedia jasa pengembangan usaha, teknologi, manajemen, pemasaran dan informasi.

- Memperluas basis dan kesempatan berusaha serta menumbuhkan wirausaha baru untuk mendorong pertumbuhan, peningkatan ekspor dan penciptaan lapangan kerja terutama dengan cara:

a) Meningkatkan perpaduan antara tenaga kerja terdidik dan terampil dengan penerapan tekonologi;

b) mengembangkan usaha kecil untuk makin berperan dalam proses industrialisasi, perkuatan keterkaitan industri, percepatan pengalihan teknologi dan peningkatan kualitas SDM;

c) mengintegrasikan pengembangan usaha dalam konteks pengembangan daerah, sesuai dengan karakteristik pengusaha dan potensi usaha unggulan di daerah.

- Mengembangkan usaha kecil untuk makin berperan sebagai penyedia barang dan jasa pada pasar lokal.

- Membangun koperasi yang diarahkan dan difokuskan pada upaya-upaya untuk: (i) membenahi dan memperkuat tatanan kelembagaan dan organisasi koperasi menciptakan iklim dan lingkungan usaha yang kondusif bagi kemajuan koperasi serta kepastian hukum yang menjamin terlindunginya koperasi dan/atau anggotanya dari praktek-praktek persaingan usaha yang tidak sehat; (ii) meningkatkan pemahaman, kepedulian dan dukungan pemangku kepentingan (stakeholders) kepada koperasi; dan (iii) meningkatkan kemandirian gerakan koperasi.

- Mengembangkan program kemitraan dengan besar usaha baik lewat sistem Bapak-Anak Angkat, PIR, keterkaitan hulu-hilir (forward linkage), keterkaitan hilir-hulu (backward linkage), modal ventura, ataupun subkontrak.

- Pengembangan sentra industri kecil dalam suatu kawasan apakah berbentuk PIK (Pemukiman Industri Kecil), LIK (Lingkungan Industri Kecil), SUIK (Sarana Usaha Industri Kecil) yang didukung oleh UPT (Unit Pelayanan Teknis) dan TPI (Tenaga Penyuluh Industri).

- Menyiapkan strategi dan kebijakan yang berpihak pada masyarakat, seperti menyiapkan program ketahanan pangan secara berkelanjutan, mempertahankan kemampuan daya beli masyarakat miskin dan tertinggal, langkah-langkah Pemerintah Pusat dalam mengembangkan subsidi langsung tunai dapat pula dioptimalkan karena terbukti efektif menghindari merosotnya kemampuan daya beli masyarakat secara luas, termasuk di Kota Bandung walaupun dalam beberapa sisi direview agar berhasil dan tepat guna dalam mendongkrak daya beli masyarakat.

- Kemampuan daya beli masyarakat sangat dipengaruhi oleh tingkat pendapatan masyarakat. Sedangkan faktor yang mempengaruhi tingkat pendapatan itu sendiri adalah lapangan pekerjaan yang pada akhirnya akan mendatangkan penghasilan atau upah. Tingkat pendidikan seseorang berperan juga dalam menentukan lapangan pekerjaannya.

- Meningkatkan laju pertumbuhan ekonomi (LPE) yang tinggi dan berkelanjutan (sustainability of economic growth). Dengan mempertahankan dan meningkatkan pertumbuhan ekonomi yang tinggi maka secara tidak langsung akan meningkatkan daya beli masyarakat Kota Bandung. 


\section{DAFTAR PUSTAKA}

Bendavid-Val, Avrom, (1991). "Regional and Local Economic Analysis for Practitioners, Praeger

Badan Pusat Statistik., Propinsi Jawa Barat Dalam Angka, berbagai edisi. ., Kota Bandung Dalam Angka, berbagai edisi.

Bank Indonesia. "Statistik Ekonomi Keuangan Daerah Jawa Barat dan Kota Bandung, Bank Indonesia Bandung, berbagai edisi

Indonesia Human Development Report (2004), The Economics of Democracy Financing Human Development in Indonesia, BPS - Bapenas - UNDP

Perda No. 6 Tahun (2004). "Kebijakan Pengembangan Ekonomi Kota Bandung". Pemerintah Kota Bandung

Rosen, Harvey S., (2008), Public Finance, 9th ed. IRWIN

Sekaran, Uma, (2000), Research Methods for Business, a Skill Building Approach, 3rd ed., John Willey \& Sons, Inc.

Saaty, Thomas L. (1989). Decision Making For The Leaders : Analytical Hirarchy Process for Decisions in A Complex World. 3rd . RWS Publications. Pittsburgh

Van den Berg, Hendrik, (2001), Economic Growth and Development, McGraw-Hill International Edition.

\section{CURRICULUM VITAE}

Name

Place/Date/Birth

Social Identity Number

Gender

Religion

Home Address

Office
: Bayu Kharisma

: Bandung, October 28, 1976

: $\quad 197610282001121004$

: Male

: Islam

: Jl. Gading Barat 1 no. 9 Bandung Komplek Puteraco Gading Regency, Soekarno-Hatta

: Faculty of Economics and Business (FEB FE 
UNPAD), Padjadjaran University Bandung

Phone

Areas of Expertise

E-Mail
禺 (022) 7335064

HP. 08179200922

: Statistics, Applied Econometrics, Agricultural Development, Public Economics, and Economic Development

: bayu_kharisma@yahoo.com

\section{FORMAL EDUCATION :}

Education
: 1. Bachelor of Economics (S.E), Economics and Development Studies, Faculty of Economics, Padjadjaran University, 19952000

2. Master of Management (M.M). Postgraduate Bogor Institute of Agriculture, 2000-2002

3. Master of Economics (M.E), Graduate School of Economics. Faculty of Economics. University of Indonesia, 20042006

4. Doctoral Program in Economics, Faculty of Economics and Business, Gadjah Mada University, 2010-present

\section{NON FORMAL EDUCATION}

1. PIM Agribusiness Management Instructor Training in Cianjur district, a cooperation between the LAN and the Local government of Cianjur, 2004

2. Training participant for Econometrics Data Panel, Department of Economics, University of Indonesia, 2005

3. Training participant "Applied Computable General Equilibrium" CEDS FE UNPAD, 2006

4. Training participant "Training for Trainers, Jenjang Fungsional Perencana (JFP) , Bappenas" Gadjah Mada University, 2006

5. Training instructor "Analytical Hierarchy Process (AHP) and Analytical Networking Process (ANP)" CEDS and the University of Bengkulu, 2007

6. Workshop Committee for Economic Planning and Investment Strategy, Regional Cooperation of Research Laboratory, the Public Service and Economic Studies (CEDS) FE-UNPAD and West Halmahera DPRD, 2007

7. Training Committee "Analytical Hierarchy Process (AHP) and Networking Analytical Process (ANP)" CEDS and the University of Bengkulu, 2007

8. Short Course in Public Private Partnership (PPP), Miyazaki University and International University of Japan (IUJ), 2009

9. Workshop on Household Survey Analysis with STATA, Department of 


\section{Bayu Kharisma}

Economics, Gadjah Mada University in 2012

\section{ORGANIZATIONAL EXPERIENCE :}

1. CEDS (Center for Economics and Development Studies) Research Staff FEB UNPAD, 2002 - present

2. Research Assistant on Natural Resources Research Center (PPSDAL) UNPAD, 2003

3. Research Staff Division of Institutional Innovation, Research and Community Services (SBRC) Padjadjaran University, 2009 - present

4. Research Staff on Center of Agricultural Policy Analysis (CAPAS) UNPAD, 2007

5. Chief Executive "Jenjang Fungsional Perencana" (JFP) for Primary and Junior Level. Bappenas 2008-2010

6. Secretary for Administration, Finance and Infrastructure on Master of Applied Economics (MET), Faculty of Economics and Business. Padjadjaran University Graduate Program, 2007-2010

\section{RESEARCH :}

1. Research Assistant at the "Assessment of Trade and Industry Policy in order to Increase Exports and Facing the Global Recession", Cooperation between CEDS UNPAD with Minister for the Economy, Finance and Industry, 2002

2. Research Assistant at the "Special Province Regulation Draft of Papua, Natural Resource Reserve Studies", a cooperation between the Natural Resources Research Center (PPSDAL) UNPAD with Environmental Impact Agency of Papua Provinces, 2003

3. Surveyor on "Export Study On Regional Autonomy Era", a cooperation of National Agency for Export Development (BPEN) and CEDS UNPAD, 2002

4. Researcher on "Guidelines for the Formulation of Promotion and Investment in West Java", a collaboration of UNPAD Institute of Management with the West Java BPPMD, 2003

5. Researcher on "Investment Assessment in order to Accelerate Development in Cianjur City", 2003

6. Researcher and Surveyor on "Preparation of IKM Business Plan in West Java", 2003

7. Research Assistant at "The BPEN Masterplan Study", a cooperation between CEDS UNPAD with the National Agency for Export Development (BPEN), 2003

8. Accreditation Drafting Team members Department of Economics and Development Studies FE UNPAD -2003

9. Researcher on "Investment and License Assessment in Order to Accelerate Development in Cianjur City", 2003

10. Surveyor on "The Strategic Plan to increase Revenues from the Tax Sector and Anticipates the Regional Development Acceleration 2006", CEDS FEUNPAD and West Java Bappeda, 2006

11. Researcher on "Analysis of the Economic Potential of Bekasi" CEDS FEUNPAD and Bekasi BAPPEDA, 2006 
12. Researcher on "Academic Manuscript Preparation on Long Term Development Plan (RPJP)" a collaboration Tasikmalaya BAPPEDA and CEDS, 2006

13. Researcher on "Tracer Study of BBPPEl Education and Training Service User" CEDS UNPAD and BBPPEI FE-2006

14. Member of the Drafting Team of Competitive Institution-Based Grant Program Department of Economics and Development Studies FE UNPAD2007

15. Surveyor on "The Welfare Improvement Strategy, Poverty and Unemployment Reduction in Tanah Bumbu, South Kalimantan Province", CEDS UNPAD FE-2007

16. Researcher on "Competitive Study on Industry and Retail Trade Sector" a cooperation between Business Competition Supervisory Commission (KPPU) and CEDS FE-UNPAD, 2007

17. Researcher on "Regoverning Markets: Synthesis of the NationalMeso and Local Meso Studies for the Study Countries". UNPAD Agricultural Policy Analysis Center and Michigan State Unversity, 2007

18. Researcher of Evaluation Criteria and Principles of Regency / City Acceptance Rate Determination in the province of West Java. CEDS FE UNPAD - Decentralization Bureau of West Java Province. 2008

19. 19. Economic Policy Evaluation Study Investigator to Increase Buying Power of Bandung Society. Bandung City BAPPEDA-CEDS FE UNPAD, 2008

20. 20. Regional Potential Revenue (PAD) Researcher of Hotel Tax, Restaurant, C Minerals, Markets, and Parking. An Approach Through Business Typology in Bandung regency. CEDS FE UNPAD, 2009

21. Researcher on "Development of Rice Industry Supply Chain Policies to Achieve Food Sufficiency in West Java", (Bayu Kharisma et al, 2010) Research Center for Development of Institutional Innovation SBRC UNPAD, October 31 th, 2010

22. Researcher on "The Simulator Prototype of Rice Industry Supply Chain System Development Policy to Achieve Food Sufficiency in West Java", (Bayu Kharisma et al, 2010), Research Center for Development of Institutional Innovation SBRC UNPAD, October 31th, 2010

\section{COMPUTER SKILLS AND MASTERY :}

Windows Operating System, Mac Operating System, MS Office (MS Word, MS Excel, MS Acces, MS Powerpoint), Mathematica, Statistical Analyst System (SAS), SPSS, Eviews, STATA, StatPlus, PhStat, MegaStat, Minitab, Super Decision (Analytic Hierarchy Process (AHP) - Analytic Network Process (ANP) software), LINDO dan Expert Choice

\section{SEMINARS \& WORKSHOPS :}

1. National Seminar on "The Potency and Problems of Managing Coastal Areas and Small Islands in Relation to Regional Autonomy, Bogor Agricultural Institute, 2001

2. National Seminar on "Policies and Strategies to improve BPR", MM-UNPAD, 


\section{Bayu Kharisma}

2002

3. National Seminar on "The Benefits of Futures Exchange In Real Sector Development and Derivatives", Bogor Agricultural Institute, 2001

4. UNPAD Department of Economics and Development Studies workshop of "Finding Islamic Economics Teaching Format", 2002

5. One Day Seminar "Economic Recovery: Now and Beyond", MM-UNPAD, 2002

6. National Seminar on Bank Indonesia regarding "Money Laundering Policy and its Direction in Indonesia", 2002

7. Public Lecture: Issues in Modern Economic Science: Thought and Policy, Professor. Dr. Robert Rich (Professor of Monash University), Bandung, 2004

8. Limited Discussion "Indonesian Presidential Candidates Debate of the Democratic Party and the Indonesian Democratic Party of Struggle on Economic Perspectives". Department of Economics, University of Indonesia, 2004

9. Discussion of "Political Economic and Institutions Study in the Age of Decentralization", Department of Economics, University of Indonesia, 2005

10. Limited discussion "Planning in Economic Development at the Era of Globalization and Decentralization in Indonesia". Department of Economics, University of Indonesia, 2005

11. Limited Discussion "Regional Head Election (PILKADA), What and How? University of Indonesia, 2005

12. National Seminar on "Whitepapers of Agriculture and Industrial Policy in Indonesia", United Nations Support Facility for Indonesian Recovery (UNSFIR), 2005

13. International Seminar and Symposium on Implementation of Islamic Economics to Positive Economics in The World as Alternative of Conventional Economics System: Toward Development in The New Era of The Holistic Economics. Jakarta, 24 Juli 2008

14. Guest Seminar: "Does Sending Farmers Back to School Have an Impact? A Spatial Econometric Approach ". The Australian National University and Padjadjaran University, 2007

15. One Day Seminar on "Quantitative Methods Studies of Science", Padjadjaran University Graduate Program, 2009

\section{PUBLICATIONS:}

1. "Evaluation of Bandung City Government Strategic Programs in Economical Efforts to Strengthen and Increase the Ability of Public Purchasing Power: A Review of Public Policy Analysis." Journal Vol. No. 6. February 1, 2010 ". 3rd Diploma Journal of the Faculty of Economics and Business Universitas Padjadjaran Bandung.

2. "The Effect of Government Spending On Education Quality Sector: A Case Study on Junior High School Level in Indonesia". Journal Vol. No. 5. February 1, 2009. $3^{\text {rd }}$ Diploma Journal Faculty of Economics and Business Universitas Padjadjaran Bandung.

3. "Characteristics and Performance of Rice Industry Supply Chain System in West Java Province". (Tommy Perdana, Dwi Purnomo and Bayu Kharisma). SOCA Journal Udayana University Bali, July 2010 Edition

4. "Restructuring Agrifood Chains in Indonesia: National and Local Meso" 
(Bayu Kharisma et. al). Michigan State University, USA and Center for Chinese Agricultural Policy, PRC. 2007

5. "Formulating Business Strategy for Feedlot Company in West Java." Economic Analysis Profile of West Java " Chapter Book a collaboration with ISEI, 2003

6. "Convergence of Income Among Provinces in Indonesia, 1984-2008: A Panel Data Approach" (Bayu Kharisma and Samsubar Saleh). $5^{\text {th }}$ best paper award in the Journal of Indonesian Economy and Business (JIEB), Gadjah Mada University, Jogjakarta, May Edition, 2013.

7. "The Role of Government on its Education Quality and Provision: The Case of Public Junior Secondary School among Provinces in Indonesia" (Bayu Kharisma and Viktor Pirmana). European Journal of Social Sciences. Volume 37 Issue 2 February 2013

8. "The Impact of School Operational Aid (BOS) Against Dropout Rate In Indonesia: Difference in Difference Analysis," Journal of Applied Quantitative Economics Udayana University Bali, Vol. 6, No. 1, (pp. 1-70), February, 2013

I declare that what I write is my best experience and I declare that this $\mathrm{CV}$ is really describes my qualifications and experience.

Bandung, September 2, 2013

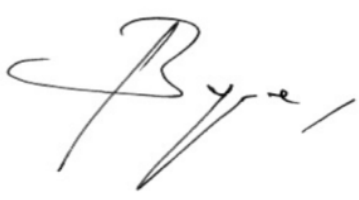

Bayu Kharisma.SE.MM.ME 